\title{
Problematyka wychowania na łamach „Dwutygodnika dla Kobiet” (1880-1885)
}

Rozwój prasy polskiej w zaborze pruskim był zależny od warunków określanych przez prawo i politykę rządu zaborcy. Choć początkowo swobody bardzo ograniczano, w drugiej połowie XIX w. ich zakres stopniowo się powiększał. Władze pruskie zezwalały na ukazywanie się gazet i czasopism, pozostających w opozycji do systemu politycznego, a możliwość jego krytykowania była znaczna. Dlatego też głównym celem prasy polskiej stała się walka z systemem zaborcy i obrona narodowości polskiej. Jednak mimo stosunkowo szybkiego rozwoju prasy, nieliczne tytuły ukazywały się przez dłuższy okres i zyskiwały sobie szerokie rzesze czytelników ${ }^{1}$.

Wielkopolska stanowiła tę dzielnicę zaboru pruskiego, która dominowała pod względem wydawnictw prasowych nad Śląskiem, Pomorzem czy Warmią i Mazurami². Wśród pism wielkopolskich, których głównym ośrodkiem wydawniczym był Poznań ${ }^{3}$, istniały także czasopisma adresowane specjalnie do płci pięknej ${ }^{4}$. Pierwsze pismo dla kobiet, powstałe w zaborze pruskim, nosiło nazwę „Dziennik

* Dr, Zakład Teorii Wychowania i Deontologii Nauczycielskiej, Instytut Pedagogiki, Wydział Pedagogiki i Psychologii, Uniwersytet Kazimierza Wielkiego w Bydgoszczy, ul. Chodkiewicza 30, 85-064 Bydgoszcz.

1 W. J a k ó b c z y k, Prasa w Wielkopolsce (1859-1918), [w:] Historia prasy polskiej. Prasa polska w latach 1854-1918, red. J. Łojek, Warszawa 1976, s. 199-201; J. Ł o j e k, J. M y ś I ín s k i, W. Wła d y k a, Dzieje prasy polskiej, Warszawa 1988, s. 52.

2 Do czynników sprzyjających rozwojowi prasy w Wielkopolsce zaliczano powszechniejszą niż w pozostałych zaborach oświatę, a więc i alfabetyzację, większą zamożność czytelników (szczególnie w warstwie chłopskiej), a także zaangażowanie w sprawy narodowe, za: J. Ł o j e k, J. M y ś I i ń s k i, W. Wła d y k a, Dzieje prasy..., s. 48, 53.

${ }^{3}$ W zaborze pruskim, w latach 1864-1918 wydawano ok. 580 tytułów polskich, z czego w Poznaniu 271, za: tamże, s. 53.

4 Jak podaje Z. Lewartowska, definicja prasy kobiecej jest krótka: „[...] grupa czasopism, głównie tygodników, redagowanych pod kątem potrzeb czytelniczych kobiet"; Z. L e w a r t o w s k a, Prasa kobieca i rodzinna, „Zeszyty Prasoznawcze” 1975, t. XVI, nr 4, s. 65. 
Domowy"5 i ukazywało się w latach 1840-1848, kolejne, zainicjowane po długiej, bo 32-letniej przerwie, to „Dwutygodnik dla Kobiet” (dalej DdK).

Niniejsze opracowanie ma na celu nie tyle charakterystykę samego czasopisma, ile ukazanie problematyki dotyczącej wychowania, która zajmowała na jego stronach stosunkowo wiele miejsca. Istotne jest także uzupełnienie istniejącego już dorobku badawczego, dotyczącego wychowania dzieci i młodzieży na terenie Wielkopolski pod jarzmem pruskiego zaborcy ${ }^{6}$. Tekst ten służy także ukazaniu, jaki w trudnych warunkach zaboru był udział prasy polskiej (na przykładzie DdK) w wychowaniu młodego pokolenia i wspieraniu rodziców, wychowawców i nauczycieli w tym procesie ${ }^{7}$. Konieczne jest tu jednak wyjaśnienie zakresu problemowego poniższych rozważań, co wynika ze specyfiki rozumienia w badanym okresie pojęcia wychowania. Wychowanie bowiem rozumiano jako wszechstronne wykształcenie duszy, umysłu i ciała wychowanka, dlatego też poruszone tu zastaną problemy wychowania moralnego, religijnego, fizycznego, a także kształ-

5 „Dziennik Domowy. Pismo poświęcone życiu domowemu, familijnemu i towarzyskiemu”- dwutygodnik wydawany pod redakcją Napoleona Kamieńskiego, adresowany był dla kobiet i starszej młodzieży. Celem pisma było budzenie zainteresowań społecznych i politycznych, a także szerzenie oświaty i czytelnictwa; Z. Z a l e s k a, Czasopisma kobiece w Polsce. Materiały do historii czasopism. Rok 1818-1937, Warszawa 1938, s. 37; zob. też: „Dziennik Domowy” [w:] J. F r a n k e, Polska prasa kobieca w latach 1820-1918, Warszawa 1999, s. 50-58

${ }^{6}$ Patrz np.: J. B e n y s k i e w i c z, Rola rodziny w zachowaniu narodowości w warunkach zaboru, [w:] Rola Wielkopolski w dziejach narodu polskiego, red. S. Kubiak, L. Trzeciakowski, Poznań 1979; W. M o l i k, Drogi edukacji córek ziemiańskich w Wielkopolsce w XIX i na początku XX wieku, [w:] Humanistyka i płeć. Studia kobiece z psychologii, filozofii i historii, red. J. Miluska, E. Bakszysz, Poznań 1995; M. A bra m, Problem wykształcenia kobiet w publicystyce poznańskiej XIX wieku. Studium porównawcze, [w:] tamże; K. S z a fe r, Dzieciństwo we wspomnieniach wielkopolskiej inteligencji i ziemiaństwa z przełomu XIX i XX wieku, [w:] Dziecko w rodzinie $i$ społeczeństwie. Dzieje nowożytne, red. K. Jakubiak, W. Jamrożek, Bydgoszcz 2002; K. S z a f e r, Matka - opiekunka - społecznik. Rola kobiety w Wielkim Księstwie Poznańskiem na przełomie XIX i XX wieku, [w:] Partnerka, matka opiekunka. Status kobiety w dziejach nowożytnych od XVI do XX wieku, red. K. Jakubiak, Bydgoszcz 2000; J. H e I l w i g, „Kościół i Szkoła” 1846-1848 o wychowaniu w rodzinie, [w:] Rodzina jako środowisko wychowawcze w czasach nowożytnych, red. K. Jakubiak, Bydgoszcz 1995; K. A d a m c z y k, „Do wychowania synów moich. Uwagi generała Władysława Zamoyskiego” - przykład poglądów na wychowanie i kształcenie dzieci arystokratów polskich w drugiej połowie XIX wieku, [w:] tamże; K. K a b z i ń s k i, Wkład polskiej rodziny wiejskiej w proces narodowego przetrwania w okresie Wielkiego Księstwa Poznańskiego, [w:] Wychowanie w rodzinie od starożytności po wiek XX, red. J. Jundziłł, Bydgoszcz 1994; M. N a w r o t, Wartości i tradycje narodowe w nauczaniu domowym w Wielkopolsce $w$ drugiej połowie XIX i początkach XX wieku w świetle ówczesnej prasy, [w:] Ideały wychowania $i$ wzory osobowe narodu polskiego w XIX i XX wieku, red. E. Kryńska, Białystok 2006; D. A p a n el, Patriotyczna postawa Dzieci Wrzesińskich jako swoisty etos wychowania w dziejach narodu polskiego, [w:] tamże.

7 O znaczeniu prasy w badaniach historyczno- pedagogicznych pisali m.in.: J. H e I I w i g, Czasopiśmiennictwo polskie okresu zaborów jako źródło do badań nad rolą rodziny w wychowaniu (na przykładzie zaboru pruskiego), [w:] Wychowanie w rodzinie od starożytności...; A. K i c o w s k a, Prasa jako źródło w badaniach historii wychowania, [w:] Metodologia w badaniach naukowych historii wychowania, red. T. Jałmużna, I. G. Michalscy, Łódź 1993; t a ż, Prasa jako źródło w badaniach historyczno-edukacyjnych (wybrane problemy), [w:] Konteksty i metody w badaniach historyczno-pedagogicznych, red. T. Jałmużna, I. G. Michalscy, Kraków 2004; B. K r z y w o b ł o c k a, Prasa jako źródło historyczne, [w:] Metody i techniki badawcze w prasoznawstwie, t. 3, Warszawa 1971; W. P i s a r e k, Analiza zawartości prasy, Kraków 1983. 
cenia umysłu dzieci i młodzieży ${ }^{8}$. Przestrzenią dla wychowania na łamach analizowanego czasopisma czyniono głównie dom rodzinny, stąd analizie poddane będzie w głównej mierze tzw. wychowanie domowe, którego główną realizatorką czyniono przede wszystkim matkę. Niemniej jednak na łamach DdK sporadycznie pojawiały się teksty na temat wychowania dzieci i młodzieży w placówkach i instytucjach wychowawczych, dlatego ta problematyka zostanie tutaj również poruszona. Ponieważ pismo adresowane było do płci pięknej, wiele miejsca poświęcono wychowaniu i wykształceniu dziewcząt, choć znaczna liczba artykułów mówiła o wychowaniu dzieci i młodzieży obojga płci.

Pierwszy numer analizowanego czasopisma (pod pełną nazwą „Dwutygodnik dla Kobiet. Pismo Beletrystyczne i Naukowe") ukazał się 2 października 1882 r. w Poznaniu. Dwutygodnik wychodził w co drugą sobotę. Za nakład i redakcję odpowiedzialne były Teresa Radońska (od 1880 do marca 1883 r.) i Teofila Radońska ${ }^{9}$ (do 1885). Odbiorcami pisma były kobiety z zaboru pruskiego, głównie z Księstwa Poznańskiego, nie docierało ono do czytelników w Królestwie Polskim ${ }^{10}$. Adresowano je głównie do kobiet $z$ warstw ziemiańskich, inteligencji, bogatego mieszczaństwa. Jak podaje Zofia Zalewska, pismo uważano za poważne i stojące na wysokim poziomie literackim i naukowym ${ }^{11}$. Bogaty i wartościowy był także jego układ. Rozpoczynało się zwykle artykułem wstępnym o tematyce historycznej, wychowawczej, życiu domowym i rodzinnym, pracy i moralności, a zdarzało się, że numer otwierano wierszem. W treści nie brakowało artykułów o tematyce literackiej, zarówno polskiej, jak i obcej, szkiców z podróży, powie-

${ }^{8}$ Jeden z czołowych publicystów pedagogicznych badanego okresu, Henryk Wernic, pisał: „Wychowanie ma zarówno na względzie ciało jak i duszę i umysł dziecka [...]. Dzisiejsza więc nauka wychowania uważa ciało za misterne narzędzie duszy i zgodnie z tym troszczy się o jego wszechstronne wykształcenie. Ceni jako istotne dobro: zdrowie, siłę, miłą powierzchowność, ale jednocześnie wielki kładzie nacisk na wykształcenie umysłu i serca"; H. W e r n i c, Praktyczny przewodnik wychowania, Warszawa 1891, s. 8.

9 Teofila Katarzyna Zofia Radońska (1846 - ok. 1913). Wykształcona w Poznaniu w żeńskiej szkole kierowanej przez M. Mottego. W 1872 r. wydała Krótką gramatykę polską dla uczącej się młodzieży, w sposób łatwy i przystępny opracowaną. Publicystka, pisała także wiersze, pracowała nad przekładami. Swoje prace publikowała w pismach poznańskich. Od 2.X.1880 redagowała w Poznaniu DdK, później „Tygodnik Beletrystyczny i Naukowy” (1885-1887) i „Dom Polski. Pismo Beletrystyczne i Naukowe"(1888-1889). Prowadziła w Poznaniu pensjonat dla dziewcząt, wykładała religię na pensji żeńskiej. W latach 1893-1985 wraz z Józefem Chociszewskim redagowała w Inowrocławiu „Dziennik Kujawski”. Nigdy nie założyła rodziny, zmarła w domu starców pod Krakowem; Teresa Radońska - młodsza siostra przyrodnia Teofili, nauczycielka, autorka powiastek Szpilka miss Nelly i Powieści o minionym szczęściu, zamieszczonych na łamach „Dwutygodnika dla Kobiet”. Siostry, obok redagowania czasopisma, pisywały do niego artykuły, powiastki, pisały recenzje i omówienia książek; za: W. A l b r e ch t-S z y m a n o w s ka, Radońska Teofila, [w:] Polski słownik biograficzny [dalej: PSB], red. E. Rostworowski, t. 29, Wrocław 1986, s. 739; zob też: J. C h o c i s z e w s k i, Piśmiennictwo polskie w życiorysach znakomitych pisarzy przedstawione dla ludu polskiego i młodzieży, wyd. III, Poznań 1893, s. 307; K. E s t r e i c h e r, Bibliografia polska XIX stulecia. Lata 1881-1900, t. 4: R-Z, Kraków 1916, s. 8; J. Data, Problematyka literacka czasopism poznańskich w latach 1869-1896, Gdańsk 1984, s. 173-174, 177-178; Wielkopolski słownik pisarek - projekt badawczy Pracowni Krytyki Feministycznej Instytutu Filologii Polskiej UAM, we współpracy z Interdyscyplinarnym Centrum Płci Kulturowej i Tożsamości UAM, patrz: http://pisarki.wikia.com/wiki/Teofila_i_Teresa_Rado\%C5\%84skie.

$10 \mathrm{J.} \mathrm{F} \mathrm{r} \mathrm{a} \mathrm{n} \mathrm{k} \mathrm{e,} \mathrm{Polska} \mathrm{prasa...,} \mathrm{s.} 191$.

11 Z. Z a le s k a, Czasopisma..., s. 91. 
ści, obrazków i nowel w odcinkach. Sporo miejsca zajmowały też korespondencje z różnych części kraju (Warszawy, Poznania, Krakowa), a także z zagranicy (autorem listów z Drezna był J. I. Kraszewski). Czytelniczki znajdowały w piśmie doniesienia z dziedziny teatru, na bieżąco informowano o interesujących, istotnych wydarzeniach społecznych oraz kulturalnych (w dziale „Rozmaitości i rzeczy bieżące”). W „Kronice literackiej” zamieszczano sprawozdania i recenzje nowych książek, głównie polskich i przeznaczonych dla kobiet, ukazujących się na terenie wszystkich trzech zaborów. Nie brakowało także pismu wymiaru praktycznego - wskazówek dotyczących różnych sfer życia kobiecego. Dawano np. wskazówki na temat prania, czyszczenia odzieży, zamieszczano przepisy kulinarne w działach „Przepisy praktyczne”, „Z gospodarstwa domowego” i „Z gospodarstwa kobiecego”. Dla zainteresowanych podawano co jakiś czas przypomnienia ogrodnicze. Istotne i przydatne w domowym gospodarstwie były z pewnością ukazujące się co jakiś czas porady związane z higieną, zdrowym trybem życia i lecznictwem domowym. Każdy numer kończył się łamigłówką czy szaradą. Na ostatniej stronie zamieszczano także ogłoszenia i reklamy - najczęściej szkół i pensjonatów dla młodzieży, wydanych nowości książkowych czy kursów kształcących w różnych dziedzinach.

DdK był pismem o charakterze antyemancypacyjnym ${ }^{12}$. Opowiadał się za tradycyjnym podziałem ról kobiecych i męskich. Jak podaje Jerzy Fanke, na łamach tego periodyku próbowano utrzymać poglądy na temat roli i przeznaczenia kobiet, które nawet w kołach umiarkowanych reform uważane były za przestarzałe i nieaktualne ${ }^{13}$. Już w pierwszym numerze redakcja w artykule wstępnym wyraźnie podkreślała rolę i znaczenie kobiety w życiu narodowym i społecznym, oddzielając specyfikę pól działania mężczyzn i kobiet, dla tych drugich pozostawiając jedynie koło rodzinne (rolę żony i matki, wychowawczyni, patronki domowego ogniska i gospodyni). Szczególnie istotnym polem pracy kobiecej była mozolna i systematyczna walka o utrzymanie polskich tradycji, obyczajów poprzez patriotyczne i religijne wychowanie dzieci i młodzieży, krzewienie cnót i szerzenie oświaty, wiary i narodowości w lokalnej społeczności:

${ }_{12}$ W jednym z artykułów przewodnich w 1881 r. określono wyraźnie stosunek do emancypacji, a także pogląd na rolę i miejsce kobiety w społeczeństwie, pisząc: „Jednym z wyrazów, najczęściej w teraźniejszych czasach używanym i powtarzanym jest wyraz emancypacja, a jednak brzmi on obco w uszach naszych, jako płód nie naszego nieba i nie naszych potrzeb [...]. Wyraz emancypacja rozmaicie bywa pojęty i tłumaczony: może być emancypacja z zasad i przepisów wiary, z tradycji, która dzieci jednego narodu łączy węzłem miłości i obowiązku, emancypacja z porządku ustalonego w rodzinie - takiej nie chcemy; emancypacja z przyzwoitości zwyczajów dobrego wychowania szacunku dla siebie i drugich - i taka nam się nie podoba; na koniec emancypacja z próżności, lenistwa, wygódek i tysięcznych małostek - której z całego serca przyklaśniemy z tem tylko nadmienieniem, że na to nie trzeba było potrzeba zapożyczać wyrazu z zagranicy, bo taka emancypacja była od dawna zasadą prawdziwie chrześcijańskiego wychowania [...]. Oj, zaprawdę, jeśli gdzie, to nie u nas uskarżać się można na upośledzenie kobiety, na mały zakres jej działania i będzie tak zawsze, póki niewiasta polska, wierna tradycji rodzinnej, zostanie tym, czym ją poważny obyczaj przodków urobił i mieć chce: zdobną w skromność i powagę, pracowitą, gospodarną, a światłą i wykształconą, zadowoloną kółkiem domowym, a zdolną zdobić najpierwsze salony; pokojem, duszą i szczęściem domowego ogniska, spójnią rodziny, orędowniczką cierpiących - słowem - doskonałą chrześcijanką", [w:] Słówko o znaczeniu emancypacji u nas, „Dwutygodnik dla Kobiet” [dalej DdK] 1881, nr 20, s. 197; zob. też: [P. M.], O potrójnej pracy kobiet, tamże, nr 14, s. 125-126.

13 J. F r a n k e, Polska prasa..., s. 191. 
Wysokie nakreślamy stanowisko kobiecie polskiej, zadanie stawiamy jej szczytne, choć trudne, pełne poświęcenia, ale i w błogosławieństwo bogate, ukryte, ciche i nierozgłośne, ale w owocach, skutkach, korzyściach widoczne i jawne [...]. Postawiona jako matka nad dzieckiem, jako gospodyni nad domem, jako pani nad czeladzią i ludem wiejskim, ma kobieta niezmiernie wielkie i obszerne pole do pracy $^{14}$.

Skoro w myśl założeń programowych pisma zadaniem kobiety było w głównej mierze bycie matką i patronką domowego ogniska, problematyka wychowawcza zajmowała dużo miejsca w analizowanym periodyku. Samo pojęcie wychowania rozumiano tu bardzo szeroko:

Wychowanie w najobszerniejszym znaczeniu tego wyrazu jest nauką, jak żyć na świecie, aby się stać użytecznym członkiem społeczeństwa i istotą zadowoloną z przeznaczonego sobie losu. Nauka taka zaczyna się od najwcześniejszego wieku niemowlęctwa, nieledwie od pierwszych chwil istnienia człowieka, a kończy się właściwie dopiero z jego śmiercią ${ }^{15}$

- czytamy. Teksty z dziedziny wychowania często zamieszano na początku numeru, jako artykuły przewodnie, podkreślając tym samym wagę problematyki. Rozpoczynając drugi rocznik DdK, redakcja pisała o głównym zadaniu, jakie nakreślono pismu: „[...] przychodzenie w pomoc obowiązkom Polki-katoliczki, obowiązkom tym trudniejszym dzisiaj, im większe napotykamy trudności, mianowicie wychowania i kształcenia przyszłych pokoleń"16.

Wśród autorek artykułów poświęconych wychowaniu znajdowały się głównie kobiety, w większości podpisujące się pseudonimami, np. pod inicjałami E. z K.P. publikowała swoje teksty Emma z Kurowskich Puffke ${ }^{17}$ (cykl artykułów wstępnych Wieczorne pogadanki starej babuni), artykuły sygnowane kryptonimami R. oraz Teja pisały redaktorki Teofila i Teresa Radońskie, Hajota - to Helena Janina Boguska ${ }^{18}$, A.M.- Aniela Milewska ${ }^{19}$. Zwyczajem jednak było, że artykuły niepodpisane przez autorów pozostawały dla czytelników anonimowe. Szczególną uwagę skupiano na problematyce wychowania domowego, które w warunkach germanizacji miało za zadanie utrzymanie polskości, ducha narodowego i religii. Nie brakowało także tekstów poruszających problematykę wychowania w instytucjach - szkołach, zakładach wychowawczych itp. - choć były one publikowane znacznie rzadziej. W artykułach poświęconych szeroko rozumianemu wychowaniu dzieci i młodzieży wskazywano błędy, które w tej dziedzinie popełniano, krytykowano niewłaściwe zachowania matek, rodziców, opiekunów, wychowawców i nauczycieli, sugerując jednocześnie możliwość naprawy aktualnej sytuacji, służąc radą i pomocą w wielu aspektach pracy wychowawczej.

14 Od redakcji, DdK 1880, nr 1, s. 1; „Tem właściwym polem dla działania kobiety jest praca spokojna i cicha u ogniska domowego, praca nad wychowaniem przyszłego pokolenia i wreszcie niezbędna praca na chleb codzienny, na utrzymanie rodziny”, w: [P. M.], O potrójnej pracy..., s. 125.

15 Wieczorne pogadanki starej babuni przez E. z K. P., cz. I: O szczęściu, DdK 1881, nr 6, s. 62.

16 Od redakcji, tamże, s. 1.

17 Zob.: PSB, t. 29, s. 347-348; K. E i s t r a c h e r, Bibliografia..., t. 3: L-Q, Kraków 1911, s. 471.

18 K. E i s t r a c h e r, Bibliografia..., t. 1: A-F, Kraków 1906, s. 165.

19 Tamże, t. 3, s. 175. Na łamach „Dwutygodnika” publikowały też Seweryna Duchińska (z Paryża), Melania Parczewska, Maria Kierska, Agnieszka Baranowska czy Izabela Moszczeńska, za: Z. Z a l e s k a, Czasopisma..., s. 91. 
Wychowanie, w myśl publikowanych na łamach pisma artykułów, było podstawowym obowiązkiem matki. Stosunkowo rzadko pojawiają się w artykułach porady czy zalecenia adresowane do obojga rodziców. „Jakimi są matki, takim jest społeczeństwo i naród"20 - pisano, stawiając przed matką zadanie bycia pierwszą wychowawczynią dziecka, której praca daje podstawy dla całego przyszłego życia nie tylko jego, ale i całego społeczeństwa i narodu. „Matka daje rzeczywiste szczęście swym dzieciom, bo ona wpłynąć może na pomyślny rozwój ich sił, zdolności charakteru; od matki zależy ich życie, bo ona wpaja w nie zasady, którymi się kierując, staną się użytecznymi członkami społeczeństwa lub jego zakałą"21.

By właściwie wychować dziecko, matka powinna cechować się określonymi przymiotami osobowości. Każda z matek winna na pierwszym miejscu stawiać troskę o wychowanie dzieci i w całości poświecić im swój czas. Krytykowano te kobiety, które koncentrowały się jedynie na życiu towarzyskim czy innej działalności, powierzając obcym wychowanie dzieci'2 ${ }^{22}$ Matkę, według zaleceń publikowanych w DdK, miały charakteryzować wszelkie cnoty niewieście: powinna być pobożna, dobra, dbająca o porządek i ład, zapobiegliwa, stanowcza, rozsądna, lecz niepozbawiona „tkliwości i czułości macierzyńskiej”23. To właśnie miłość macierzyńska miała być gwarantem bliskości z dzieckiem, otrzymania zaufania z jego strony, a tym samym zapewniała skuteczność oddziaływań wychowaw$\mathrm{czych}^{24}$. Matka powinna zawsze pamiętać o tym, że całym swoim postępowaniem daje przykład dzieciom. Dlatego też musi kontrolować swoje postępowanie, przyzwyczajenia, nawyki, słabości, by nie zaszczepiały się w dzieciach. Powinna pracować nad sobą, nad swoim charakterem, należycie wypełniać swoje obowiązki, kierować się zasadami moralnymi. Postulowano także, by matki uzyskały właściwe wykształcenie, niezbędne do wypełniania obowiązków macierzyńskich i do wychowania dzieci ${ }^{25}$. „Tysiące wad, zdrożności, tysiące spaczonych ludzkich charakterów w matkach mają swe źródła: gwałtowność, lenistwo, niemoralność

20 Obowiązki Polek wobec języka narodowego, DdK 1881, nr 8, s. 62; zob. też: [R.], Kobieta u domowego ogniska, DdK 1882, nr 6, s. 61. Piękna metafora ukazywała powagę i znaczenie roli matki w wychowaniu dziecka - „Dusza dzieciny to niwa czekająca uprawy, pierwszy posiew rzucony tam przez matkę rozrasta się z czasem w bujny plon najpiękniejszych owoców, lub w chwasty, tłumiące najlepsze wrodzone skłonności. Matka podobna jest tu do sztukmistrza, zaopatrzonego w bogaty materiał: jeśli zadanie swe wypełnia starannie i umiejętnie, stworzy dzieło piękne, jeżeli nieudolną jest mistrzynią, zepsuje najbogatszy materiał i to arcydzieło Boże, powierzone jej pieczy, oddaje w dalsze ręce zeszpecone", [w:] O pierwszych zasadach wychowania, DdK 1880, nr 7, s. 53.

21 [P. M.], O potrójnej pracy..., s. 125.

22 O pierwszych zasadach..., s. 54; O zadaniu i pracy kobiet. Napisał A. Sd., DdK 1881, nr 4, s. 38; O fizycznym wychowaniu dzieci. Podał dr Klemens Kochler, DdK 1883, nr 15, s. 176.

${ }^{23}$ O pierwszych zasadach..., s. 54; [R.], Kobieta..., s. 62; Miłość rodzicielska, DdK 1882, nr 15, s. 169 .

24 O pierwszych zasadach..., s. 54.

${ }^{25}$ Wychowanie dziecka włącznie do lat sześciu przez Henryka Wernica, DdK 1881, nr 7, s. 81; [M. Sz...a], Kiedy się ma rozpoczynać wychowanie, tamże, nr 5, s. 25; [P. M.], O potrójnej pracy..., s. 125; [A. M.], Towarzystwo Przyjaciół Dzieci w Warszawie, tamże, nr 18, s. 175; [R.], Kilka słów o potrzebie ciągłego kształcenia się, DdK 1883, nr 13, s. 145-146; Pogadanki o wychowaniu przez Anielę Milewską, DdK 1885, nr 12, s. 134. 
i zepsucie, brak pojęcia obowiązków rodzinnych i brak miłości ojczyzny u kobiety, jak grzech pierworodny przechodzą z niej na potomstwo"26 - przestrzegano.

Za podstawę i fundament wszelkiego wychowania uznawano religię. Warunkiem skutecznego wychowania było oparcie wszelkich jego prawideł i zasad na podstawach zgodnych z Bożymi przykazaniami ${ }^{27}$. Matka powinna więc uczyć dziecko od najmłodszych lat prawd wiary i zasad religii katolickiej, powinna wpajać mu miłość do Boga, co miało być gwarantem sukcesów na polu wychowawczym. Kobieta zaś powinna w religii szukać celów i wartości życiowych i zgodnie z nimi realizować swe zadania wychowawcze. Nauczanie religii zalecano rozpoczynać już od kołyski, ucząc maleńkie dziecko znaku krzyża, powtarzając mu do snu modlitwy i śpiewając pieśni religijne. Kiedy dziecko nauczyło się mówić, należało wspólnie z nim rano i wieczorem powtarzać pacierz, czytywać mu Pismo Święte, żywoty świętych i inne książki o treści religijnej. Starsze dzieci, obok codziennej modlitwy, miały regularnie uczestniczyć w nabożeństwach ${ }^{28}$.

Niezwykle istotne było wychowanie patriotyczne, narodowe. Wzór dla wielkopolskich kobiet-matek miały stanowić znane i wsławione w działalności patriotycznej niewiasty, „[...] które nie z mieczem w dłoni, lecz sercem i obyczajem, hartem ducha, cichym poświęceniem i cnotą surową, wielką i czystą miłością Boga, Ojczyzny i rodziny się odznaczając, przodowały społeczeństwu naszemu w ciężkich godzinach ofiary i pogromu, [...] szafarki serca i miłosierdzia chrześcijańskiego, bogobojne kapłanki rodziny, prawdziwe Polki i służebnice Boże, niezgasłym nigdy nam przyświecające przykładem"29. Ich sylwetki przypominano np. z okazji pięćdziesięciolecia powstania listopadowego. Cytat powyższy, charakteryzujący ideały cnót niewieścich, oddaje jednocześnie zadanie i powołanie kobiety, które formułowano na łamach DdK ${ }^{30}$. Wychowanie kobiet, w myśl założeń propagowanych w piśmie, miało służyć kształtowaniu prawdziwych kapłanek idei polskiej, takich kobiet, które dla idei „[...] wyrzekają się wszelkiej życia słodyczy [...]”31, w całości poświęcając się rodzinie, Bogu i Ojczyźnie.

Przekazanie młodemu pokoleniu miłości do ojczyzny, poszanowania tradycji i obyczajów narodowych, zapoznawanie ich z dziejami własnego kraju także spoczywać miało w głównej mierze na barkach matki32 ${ }^{32}$ Dziecko, które wychowano

${ }^{26}$ [P. M.], O potrójnej pracy..., s. 125.

27 O wychowaniu dzieci. Sześć nauk powiedzianych na pasjach Wielkiego Postu w Katedrze Poznańskiej 1880 roku przez ks. W. Chotkowskiego, DdK 1881, nr 14, s. 134; O zadaniu i pracy kobiet..., s. 38; [E. z K. P.], Wieczorne pogadanki starej babuni, DdK 1883, nr 15, s. 169-170; [Teja], Staropolskie cnoty, DdK 1884, nr 13, s. 145-146

${ }^{28}$ O pierwszych zasadach..., s. 54; O wychowaniu dzieci..., s. 134; Wychowanie w stosunkach naszych, DdK 1881, nr 11, s. 89-90; [Teja], Staropolskie..., s. 145.

${ }^{29}$ W cześć matkom naszym, DdK 1880, nr 5, s. 34.

30 „W obszernym, bo 5-cio stronicowym artykule omówione zostały sylwetki Klaudyny z Działyńskich Potockiej, Emilii Szczanieckiej, Kunegundy z Platerów Ogińskiej i Klementyny z Tańskich Hoffmanowej"; zob.: tamże, s. 34-39.

31 Tamże, s. 36.

32 [P. M.], O potrójnej pracy..., s. 125; [R.], Kobieta obywatelka, DdK 1882, nr 7, s. 73; A. B a r a n o w s k a, Do matki Polski. Odpowiedź, DdK 1883, nr 21, s. 241; [B. Ł]., Słów kilka o dawnej, ale jeszcze palącej kwestii, DdK 1885, nr 17, s. 194. 
w domu pełnym „[...] atmosfery szlachetnego patriotyzmu, od niemowlęctwa pojone miłością ojczyzny, umie, gdy czas przyjdzie, służyć jej każdą pracą i poświęceniem"33. Stanowczo krytykowano zwyczaj wychowania i kształcenia dzieci poza granicami kraju, w warunkach odmiennych niż panujące w ojczyźnie, które zamiast kształcić patriotów, rodziły kosmopolitów. Nie negowano wyjazdów w celach poznawczych, lecz proces edukacji przebiegać powinien w rodzimych warunkach, przygotowując chłopców do służenia krajowi swą pracą i w razie konieczności walką zbrojną, dziewczęta zaś do bycia prawymi obywatelkami, żonami, matkami i gospodyniami, przesiąkniętymi narodowym pierwiastkiem ${ }^{34}$. Wychowanie patriotyczne należało realizować poprzez nauczanie i wpajanie szacunku do ojczystej historii, pamiątek narodowych, zapoznawanie dzieci z ziemią ojczystą, pięknem ojczystej przyrody, miejscami walk narodowowyzwoleńczych, bohaterami narodowymi i literaturą polską̧

Wychowanie religijne i patriotyczne były ze sobą ściśle powiązane. Dobrego Polaka utożsamiano z dobrym katolikiem, zaś cnoty religijne łączono z miłością do ojczyzny. Twierdzono, że im lepszym ktoś jest chrześcijaninem, tym lepszym jest patriotą ${ }^{36}$. „Nigdzie ściślej, jak u nas, z religią nie jest połączona narodowość; miłość Boga i miłość Ojczyzny"37- charakteryzowano w jednym z artykułów ten specyficzny i charakterystyczny dla polskiego narodu związek religii i patriotyzmu.

Wychowanie dziecka, w myśl zaleceń zawartych na stronach analizowanego pisma, należało zaczynać jak najwcześniej - „od kolebki”"38. Jak pisano, w niemowlęctwie dziecko nabiera umiejętności i przyzwyczajeń, które mają konsekwencje w całym przyszłym życiu. Autorka podpisująca się pseudonimem M. Sz...a sugerowała matkom, by zwracały baczną uwagę na zatrudniane do opieki nad dzieckiem piastunki i nianie, które często wywodziły się z prostego ludu, mówiły niepoprawnie i zachowywały się niewłaściwie, a często i niemoralnie. Radziła, by piastunki nigdy się nie kłóciły w obecności dzieci, nie używały obelżywych wyrazów, by poprawnie mówiły i kontrolowały swoje zachowanie. Dlatego też wybór odpowiedniej piastunki był sprawą bardzo istotną: „[...] niech nie będzie krzykliwa, sporna, zamroczona, ale wesoła, łagodna, roztropna. Gderliwość piastunki zasępia dziecko, robi je niezadowolonym i kwaśnym"39. Przestrzegano przed piastunkami, które dla własnej wygody poiły dzieci szalejem lub wódką, zaś drastyczne przykłady miały z pewnością na celu zwiększyć czujność matek przed pochopnym zatrudnianiem opiekunek do dzieci ${ }^{40}$.

\footnotetext{
${ }^{33}$ [R.], Kobieta obywatelka..., s. 73.

34 Tamże, s. 74.

${ }^{35}$ [Teja], Cudze rzeczy znać dobrze jest - lecz swoje koniecznie, DdK 1884, nr 24, s. 277-278.

${ }^{36}$ [E. z K. P.], Wieczorne pogadanki starej babuni. Patriotyzm a religia, DdK 1883, nr 8, s. 86.

37 Wychowanie w stosunkach..., s. 89; „I naszym dzieciom na twarde czasy żyć przychodzi, daj-
} my im na tę drogę żywota dwa grosze Samarytanina: miłość wiary i miłość ojczyzny [...]. Zaiste, trudne to zadanie i nie słabego wychowania owoc", [w:] Dwa grosze na drogę życia, DdK 1881, nr 21, s. 119.

${ }^{38}$ [M. Sz...a], Kiedy się ma rozpoczynać..., s. 25; zob. też: [A. M.], Towarzystwo Przyjaciół Dzieci..., s. $175-176$.

39 [M. Sz...a], Kiedy się ma rozpoczynać..., s. 25.

40 [A. M.], Towarzystwo Przyjaciół Dzieci..., s. 176. 
Ogromne znaczenie w wychowaniu dziecka miało kształtowanie moralnego charakteru, które radzono realizować jak najwcześniej, już od najmłodszych lat. „Władze moralne rozwijają się przez szczerą pobożność, przez ćwiczenie się w cnocie cierpliwości i poświęcaniu, przez pojęcie zacności i prawdziwego piękna, przez dobre uczynki, skromność i pracowitość"41 - pisała E. z K. P. Matki powinny wdrażać dzieci do prawdomówności, którą uważano za podstawę prawego charakteru, a także do skromności, grzeczności, uprzejmości. Dobrze wychowane dziecko powinno mieć szacunek wobec bliźnich, zarówno dorosłych (szczególnie rodziców, krewnych, kapłanów, nauczycieli), jak i rówieśników, także bogatych i ubogich czy nieszczęśliwych ${ }^{42}$. Należało w dzieciach tępić krnąbrność i pychę, samowolę i upór, kłamstwo i obłudę. Za niezbędne w wychowaniu dziecka uznawano posłuszeństwo i podporządkowywanie się dorosłym. Należało to jednak czynić rozsądnie i z umiarem: „[...] żądając posłuszeństwa, trzeba rozkazywać tylko rzeczy możliwe, niewiele naraz, nie wymagać obietnicy, której by dziecko dopełnić nie mogło [...], wpoić w dziecko świętość przyrzeczenia"*3. Drogą do przestrzegania zaleceń i posłuszeństwa miały być m.in. przymus, kary, łącznie z fizycznymi, szczególnie dopuszczanymi w wypadku chłopców. Jednak kary fizyczne, np. chłostę, zalecano jedynie w wypadku wyraźnej złej woli dziecka, zakazywano zaś jej stosowania, kiedy przewinienie wynikało z wrodzonej słabości czy wad ciała winowajcy. Surowe kary, jak twierdzono, kiedy były w rzeczywistości zasłużone, nie „skrzywiały” charakteru dziecka ${ }^{44}$.

By właściwie kierować rozwojem charakteru dziecka, należało dbać o to, by było ono stale zajęte - bądź to zabawą, bądź nauką lub pracą - stosowną do wieku i umiejętności. Takie postępowanie miało nie tylko przyzwyczajać malucha do pracowitości, czynnego spożytkowania czasu, lecz także miało chronić od kaprysów, zachcianek i próżności ${ }^{45}$. Zalecano, by dzieci od najmłodszych lat miały swoje zadania i obowiązki, które realizować powinny z wytrwałością i systematycznością. Nie chodziło tu tylko o obowiązkowe nauki, ale o pomoc czy wyręczanie rodziców w pracach domowych czy gospodarskich, robótki ręczne, codzienną lekturę, modlitwę, regularny udział w nabożeństwach. Konsekwentne postępowanie i respektowanie wypełniania przez dziecko zadań miało przyzwyczaić je do tego, że „[...] są w życiu świętsze i ważniejsze sprawy, aniżeli rozrywki i igraszki wesołe"46, miało zwalczać lenistwo, lekkość odstępowania od przyjętych

41 Wieczorne pogadanki...O szczęściu, s. 62.

42 O pierwszych zasadach..., s. 54; [M. Sz...a], Prawda a uszanowanie, DdK 1881, nr 7, s. 73; O wychowaniu dzieci..., s. 134; [M. Sz...a], To i owo o grzeczności, DdK 1882, nr 10, s. 109; [Teja], O delikatności uczucia. Z nauki wychowania, DdK 1885, nr 7, s. 73-74; Pogadanki o wychowaniu..., tamże, nr 12, s. 133-134; nr 14, s. 157-158.

43 O wykształceniu woli dziecka, DdK 1881, nr 25, s. 257.

44 Tamże; O wychowaniu dzieci..., s. 134; [M. Sz...a], Prawda a uszanowanie..., s. 73; t a ż, Kiedy się ma rozpoczynać..., s. 25; [Teja], Stanowczość i energia w wychowaniu, DdK 1884, nr 17, s. 193-194; Pogadanki o wychowaniu..., DdK 1885, nr 14, s. 157.

45 O pierwszych zasadach..., s. 54; Jak należy pojmować wychowanie jędrne i zdrowie, DdK 1881, nr 23, s. 233.

46 [Teja], Stanowczość i energia..., s. 193. 
zasad i chwiejność charakteru. Dlatego też krytykowano zbytnie pobłażanie obowiązkom dziecka, praktykowane często odstępowanie od przyjętego planu czy obowiązku z powodu zabawy, wyjazdu czy innej przyjemności, zalecając rodzicom wytrwałość i stanowczość w respektowaniu podjętych przez dziecko zobowiązań ${ }^{47}$.

W DdK matki znajdowały cenne wskazówki, jak wykorzystywać różne sytuacje życia codziennego do kształtowania charakteru dzieci. W myśl zasady „[...] po tym, jak kto je, poznać jego wychowanie"48, przy wspólnych posiłkach, spożywanych w gronie rodzinnym, dzieci uczyć się miały punktualności (spóźnieni nie otrzymywali posiłku), siadania według starszeństwa i godności, dziękowania za jedzenie i towarzystwo. Zwracano szczególną uwagę na toczące się przy stole rozmowy, które powinny być dostosowane do niewinnych uszu najmłodszych - krytykowanie nieobecnych, obmawianie znajomych, używanie niewłaściwego, wulgarnego słownictwa było zakazane. We wspólnych posiłkach, w których uczestniczyły dzieci, „[...]powinien panować porządek, smak dobry, przyzwoitość, stosowanie się do powszechnie przyjętych praw i zwyczajów towarzyskich [...] być powinny znakomitą szkołą moralnego i towarzyskiego wychowania"49.

By osiągnąć cel - dobrze wychować potomka, dobrego Polaka i katolika radzono rozpocząć od zbadania usposobienia dziecka i jego skłonności. Dopiero wtedy, po ich poznaniu, sugerowano dobieranie odpowiednich środków i sposobów wychowawczych. Dzieci żywe i gwałtowne radzono prowadzić surowo, stanowczo, przyzwyczajać je do spokoju i zajęć wymagających cierpliwości. Maluchy powolne i ociężałe sugerowano pobudzać do działania i ruchu fizycznego, dzieci nad wiek rozwinięte i okazujące skłonność do marzycielstwa zainteresować światem zabaw dziecięcych, krnąbrne upokarzać i skłaniać do przyznania się do błędu. Za największy błąd matek uznawano przesadne schlebianie kaprysom, słabościom i zachciankom dziecka, co powodować mogło egoizm i despotyzm, nieposłuszeństwo ${ }^{50}$.

Kilka artykułów poświęcono także nauczaniu domowemu, czyli kształceniu umysłu dziecka. Zalecano, podobnie jak w przypadku wychowania, rozpoczynać je jak najwcześniej, by przygotować dziecko do trudów późniejszej nauki. Systematyczne rozwijanie umysłu dziecka od najmłodszych lat było zadaniem matki, którą uznawano za pierwszą nauczycielkę dziecka. Nie należało, jak pisano, pozwalać dziecku spędzać czasu jedynie na swobodnej zabawie do 6-8 roku, gdyż w momencie rozpoczęcia systematycznej nauki będzie ono uczyć się niechętnie i z trudem. Główne zalecenie dotyczące rozpoczynania kształcenia umysłowego brzmiało: „Staranne, najwcześniejsze rozwijanie dziecka ułatwia mu późniejszą naukę, to ułatwienie każe mu ją pokochać - z czego najpożądańsze wynikają rezultaty"51. Podpowiadano matkom, jak przyczyniać się do pobudzania umysłu dziecięcego - miały one często rozmawiać z dziećmi, zadawać pytania, cierpliwie słuchać udzielanych przez dziecko odpowiedzi, w razie potrzeby je prostować,

47 Tamże, s. 194; Pogadanki o wychowaniu..., DdK 1885, nr 14, s. 170.

48 Przy stole, DdK 1882, nr 19, s. 217.

49 Tamże, s. 218.

${ }^{50}$ O pierwszych zasadach..., s. 54; Miłość rodzicielska, DdK 1882, nr 15, s. 169.

51 [R.], O wczesnym rozwijaniu umysłu dziecka. Kilka uwag z pedagogiki, DdK 1883, nr 20, s. 229. 
wyjaśniać otaczający świat, czytać książeczki, pokazywać obrazki, uczyć wierszyków. Oczywiście wszystkie te działania powinny być dostosowane do wieku i poziomu umysłowego malucha. Wiek, w którym powinna się rozpocząć „książkowa" nauka, powinien być również zależny od przygotowania dziecka, przeciętnie wskazywano, iż następowało to ok. 6 . roku życia ${ }^{52}$. Zwykle wtedy dziecko oddawane było pod opiekę i dozór domowego nauczyciela lub nauczycielki. Zanim jednak rozpoczęto lekcje, zalecano poznać dokładnie i ocenić stan zdrowia dziecka, jego zdolności, poziom rozwoju umysłowego, by zgodnie z nim przygotować plan i program zajęć. Czynić to powinna nauczycielka w porozumieniu z rodzicami. Nie należało w nauce początkowej przesadnie obciążać umysłu dziecka nauką kilku języków obcych, nazwami, datami itp., właściwe było kształtowanie wyobrażeń i rozwijanie pojęć. Przebieg lekcji także był ściśle określony - zajęcia z jednego przedmiotu nie powinny trwać dłużej niż godzinę (u młodszych dzieci kwadrans), miały być interesujące i zajmujące dla dziecka, pobudzające jego ciekawość i chęć zdobywania wiedzy, zaś nauczycielka miała się do nich starannie przygotowywać. Między lekcjami powinna być przerwa tym dłuższa, im młodsze dzieci. W planie dnia należało uwzględnić przerwy nie tylko na posiłki, lecz także na spacery i ruch fizyczny. Radzono kobietom, jak racjonalnie rozłożyć plan dnia dziecka, szczególnie uczącego się w domu. Podkreślano znaczenie porządku i stałych pór poszczególnych zajęć, zawłaszcza godzin lekcyjnych. Spóźnienia czy zmiany ustalonego porządku rozpraszały bowiem uwagę dziecka i, jak sugerowano, były jedną z przyczyn słabych rezultatów domowej nauki ${ }^{53}$.

Wśród metod, stosowanych przez nauczycielki, krytykowano szczególnie naukę pamięciową (zadanie wyuczenia się fragmentu z książki i odsłuchanie go bez wyjaśnień), przepisywanie za karę ustępów tekstów czy łajanie i ubliżanie

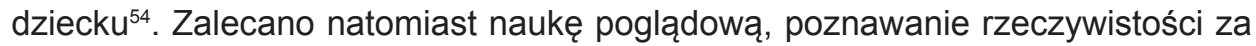
pomocą zmysłów, wyjaśnianie otaczającego świata podczas spacerów i innych sprzyjających nauce okoliczności, organizowanie doświadczeń i wycieczek edukacyjnych ${ }^{55}$.

Szczególnie podkreślano znaczenie i konieczność troski o język ojczysty. Wychowanie dzieci w poszanowaniu dla języka polskiego miało tym bardziej istotne znaczenie, że w warunkach zaboru zarówno życie szkolne, jak i całe życie publiczne zdominowane były przez język zaborcy. Prześladowanie językowe miało na celu dopełnienie tego, czego przemoc fizyczna nie mogła dokonać - „ciągłego, powolnego zadawania śmierci narodowi” ${ }^{56}$. Główną obrończynią i krzewicielką języka ojczystego uczyniono kobietę-matkę. To jej zadaniem było uczyć dzieci mowy ojczystej, troszczyć się, by posługiwano się nią w domu i to-

\footnotetext{
52 Tamże, s. 230; Pogadanki o wychowaniu..., DdK 1885, nr 14, s. 170.

${ }^{53}$ [M. Sz...a], Podział czasu, DdK 1882, nr 4, s. 37-38.

${ }^{54}$ [K. K.], Kilka uwag o ważności obowiązków nauczycielek domowych, DdK 1885, nr 18, s. $205-206$.

${ }^{55}$ [K. K.], Kilka uwag o ważności obowiązków nauczycielek domowych. O sposobie nauczania, tamże, nr 19, s. 217-218; Pogadanki o wychowaniu..., s. 170.

${ }^{56}$ Obowiązki Polek..., s. 61; zob. też: Kobieta obywatelka..., s. 74; Od redakcji, DdK 1884, nr 1, s. 1; [K. K.], Odezwa do Polek w kwestii bardzo naglącej, DdK 1885, nr 21, s. 241-242.
} 
warzystwie. Ciągłe używanie języka polskiego miało nie tylko ukazać dzieciom piękno i znaczenie mowy ojczystej, lecz także miało naprawiać germanizacyjne wpływy szkoły. „Miłością tej mowy uzbrojone dzieci polskie przez swoje matki, porzucą pogardę dla polskiego słowa, jaką obcy nauczyciele zaszczepić by chcieli w ich sercach. Niechaj każda Polka będzie nauczycielką tego słowa"57 pisano w jednym $z$ artykułów przewodnich w $1881 \mathrm{r}$.

Zalecano matkom, by uczące się w szkołach dzieci douczały w domu przedmiotów polskich, a w czasie wakacji, kiedy starsze dzieci wracały ze szkół, zorganizowały im letnią szkołę języka i historii ojczystej. Kiedy same nie miały czasu czy zdolności do prowadzenia lekcji, polecano zorganizować komplety nauczania kilkorga dzieci z okolicy pod kierunkiem domowego nauczyciela czy nauczycielki ${ }^{58}$. Jednocześnie na łamach pisma krytykowano zwyczaj zatrudniania dla najmłodszych dzieci bon cudzoziemek, Francuzek, Szwajcarek, Angielek, które, zgodnie z panującą modą, uczyły dzieci mowy w swoim ojczystym języku. Zwyczaj ten nazywano pierwszym fundamentem wynarodowienia, który tępił umysły dzieci i stawał się przeszkodą w umiłowaniu piękna języka ojczystego. Natomiast, jeśli dzieci uczyły się języka obcego, używać go miały jedynie podczas lekcji, zaś na co dzień należało posługiwać się wyłącznie językiem ojczystym ${ }^{59}$.

W 1885 r. na łamach analizowanego pisma ukazał się obszerny tekst poświęcony pracy nauczycielek domowych. Autorka, posługująca się kryptonimem K.K., wnikliwie scharakteryzowała pracę guwernantek, motywy jej podejmowania, nakreśliła obraz idealnej nauczycielki, opisując szereg niezbędnych w tej profesji cech osobowości i poziom wykształcenia. Konieczne było, by guwernantka posiadała wiedzę nie tylko z zakresu wykładanych przedmiotów, lecz także z pedagogiki, którą miała nieustannie uzupełniać i poszerzać. Istotne było to, by nauczycielka pokochała swe uczennice, by potrafiła w nich wzbudzić posłuszeństwo, miłość i szacunek dla swojej osoby. Powinna swoim przykładem i postawą stawać się wzorem dla uczennic, miała być cnotliwa i moralna, powinna unikać zabaw, rozrywek, plotek, wyzbyć się chęci podobania się i zamiłowania do strojów60.

Ponieważ pismo trafiało głównie do kobiet i poruszało problematykę dotyczącą spraw niewieścich, dlatego też bardzo dużo uwagi poświęcano zagadnieniu wychowania i wykształcenia dziewcząt. W procesie wychowania dziewcząt-córek akcentowano szczególnie rolę matki. Powinna ona swoim życiem i codziennym przykładem stać się dla córki wzorem właściwego postępowania w różnych dziedzinach życia. Wykorzystując każdą nadarzającą się okazję, miała przyzwyczajać dziewczynkę do przyszłego powołania kobiety, do radzenia sobie w rozlicznych sytuacjach dnia codziennego ${ }^{61}$. Zgodnie $z$ profilem pisma, które miało charakter antyemancypacyjny, krytykowano tzw. nowoczesne wychowanie i kształcenie

57 Obowiązki Polek..., s. 62

58 [K. K.], Odezwa do Polek..., s. 241.

59 Obowiązki Polek..., s. 62; Wychowanie w stosunkach..., s. 90; Rozmaitości, DdK 1882, nr 10, s. 120; [Teja], Cudze rzeczy..., s. 277.

60 [K. K.], Kilka uwag..., nr 18, s. 205-206.

61 O pierwszych zasadach wychowania..., s. 54. 
dziewcząt, argumentując, że „[...] uczą je rozmaitych, niepotrzebnych i zbytecznych rzeczy, że je nie dość starannie przysposabiają do przeznaczonego im zawodu, a przede wszystkim, że wykształcenie religijne często bywa zaniedbywane"62. Autorki tekstów, zwolenniczki tradycyjnego modelu wychowania dziewcząt, opowiadały się za takim kształceniem panien, by przygotować je do roli matki, żony, pani domu, troszczącej się o dobro swojej rodziny, ojczyzny i wiary. Wiele krytycznych głosów towarzyszyło kształceniu dziewcząt pod kierunkiem zagranicznych guwernantek, które często zapominały o konieczności gruntownego poznania przez uczennice nie tylko ojczystego języka, lecz także historii polskiej i religii - przedmiotów usuniętych z programów szkolnych, prowadzonych tylko w nauczaniu domowym ${ }^{63}$. Wśród nauk, które powinny znaleźć się w programie kształcenia dziewcząt, wskazywano historię, nauki przyrodnicze (fizykę, chemię, wiadomości o świecie zwierząt i roślin, higienę), gramatykę, stylistykę, literaturę, zaś za najistotniejszą i podstawową uznawano religię ${ }^{64}$. Proponowano kurs uzupełniający, który powinny przejść dziewczęta po skończeniu domowej edukacji na poziomie średnim lub nauce na pensji, włączając do niego poszerzanie wiadomości z zakresu poezji polskiej, historii narodowej, estetyki i historii sztuki, logiki, rachunkowości domowej, chemii, fizyki65.

Osobną uwagę poświęcono w kilku tekstach talentom, szczególnie nauce gry na fortepianie. Krytykowano przyjęty zwyczaj kształcenia dziewcząt w zakresie muzyki, bez względu na posiadany przez pannę talent czy zamiłowanie do tej sztuki. Najczęstszym motywem kształcenia w tym kierunku była panująca moda i pokutujące w społeczeństwie przekonanie, że każda panna z „dobrego domu” grać powinna. Tracąca kilka godzin dziennie na wprawki dziewczynka, wychodząc za mąż często o fortepianie zapominała, do czasu, aż swoje córki zapragnęła kształcić muzycznie. Zalecano więc, by do gry na fortepianie nie zmuszać, zaś nakłaniać do niej tylko dziewczęta i panny, wykazujące w tym kierunku pewien talent, który łatwo mógł się rozwinąć, pozostałym zaś sugerowano spędzanie czasu na innych pożytecznych zajęciach - rysunkach, czytelnictwie, robótkach kobiecych, pracach domowych czy w ogrodzie ${ }^{66}$. Pisano także o nauce śpiewu, którą, podobnie jak w przypadku gry na instrumencie, realizować powinny tylko dziewczęta uzdolnione. Zalecano dziewczętom częstsze zajmowanie się malarstwem, rysunkiem czy rzeźbą, które nie znajdowały szerszego zainteresowania wśród panien, a mogły przyczynić się do rozwijania zmysłu estetycznego i dobrego smaku. Pisano, iż każdy - w mniejszym, czy większym stopniu - posiada jakiś talent,

62 [E. z K. P.], Wieczorne pogadanki..., s. 169.

63 [Teja], Cudze rzeczy..., s. 277.

64 Pogadanki o wychowaniu..., s. 170.

65 [B.], Czego żąda od nas chwila obecna? Trzy listy młodej Polski z miasta do przyjaciółki na wsi, DdK 1883, nr 6, s. 61-62, nr 7, s. 73-74; nr 8, s. 85-86.

66 „Stało się dzisiaj koniecznym warunkiem wykształcenia dziewczyny, aby zbijała palce na klawiaturze fortepianu, nieodzownym wymogiem pięknej edukacji, chociażby obok tego ukrywała się najgłębsza niewiadomość, płytkość umysłu, brak nawet jasnego pojęcia muzyki, jako sztuki pięknej”, [w:] Fortepian w wykształceniu młodzieży. Pogadanka przyjaciela muzyki, DdK 1883, nr 26, s. 310; [Teja], Krótka uwaga o uprawianiu tak zwanych talentów, DdK 1883, nr 4, s. 37. 
zaś panny powinny poszukiwać go nie tylko (jak nakazywała moda) w muzyce, lecz także w pięknym, głośnym czytaniu, deklamacji czy robotach kobiecych ${ }^{67}$.

W propagowanym na łamach pisma modelu wychowania dziewcząt zwracano szczególnie uwagę na konieczność znajomości robót kobiecych. Zgodnie z tradycyjnym i odwiecznym podziałem ról i obowiązków - „[...]mężczyzna - pługiem i mieczem, kobieta - przy kądzieli i z igłą w ręku"68 - każda dziewczynka od najmłodszych lat powinna być wprawiana kroju i szycia, wyszywania i haftowania, robienia na drutach, szydełku. Prace takie miały istotny aspekt pedagogiczny i wychowawczy:

[...] dziewczynka, wcześnie zaprawiana przez naukę do tego rodzaju pracy, nabiera cierpliwości, łagodności, wyrozumiałości, tyle niezbędnej w późniejszym życiu, a że charakterystycznym znamieniem tych robót jest ich rozmaitość, obok drobiazgowości, uczennica przy pokonywaniu tysięcznych, codziennych w tego rodzaju drobiazgach trudności nabiera hartu, wytrwałości i stałości charakteru' ${ }^{69}$.

Podkreślano także, że podczas robót kobiecych w dziewczynkach wyrabia się smak, gust i poczucie piękna, a także kształci się umysł, szczególnie, kiedy samodzielnie należało obmyślać wzory linii i kształtów swych prac. Prace dziewcząt służyły w gospodarstwie domowym, zdobiły pokoje, ubierały i stroiły członków rodziny, stawały się doskonałym prezentem na każdą okazję. Podstawy tej nauki panienki powinny pobierać $\mathrm{w}$ domu rodzinnym. Zwracano jednak uwagę na konieczność wprowadzenia tego typu robót do szkół ludowych, co miało przyczynić się do rozwoju tej gałęzi rękodzielnictwa, a w konsekwencji - stać się drogą zarobku dla kobiet. W jednym z artykułów przedstawiono projekt nauczania robót kobiecych dla ludowych szkół elementarnych i wydziałowych miejskich i wiejskich ${ }^{70}$.

Matki mieszkające na wsi, właścicielki ziemskie, miały obowiązek, w myśl zaleceń formułowanych na łamach DdK, zapoznawać córki z pracą w wielu działach wiejskiego gospodarstwa kobiecego, a więc z prowadzeniem kuchni, utrzymywaniem porządku i czystości, sporządzaniem zapasów, hodowlą drobiu i trzody, ogrodnictwem, pszczelnictwem, jedwabnictwem, uprawą roślin farbiarskich i aptecznych, a także racjonalnym podziałem pracy, zarządzaniem służbą, rozkładem godzin poszczególnych zajęć, prowadzeniem rachunkowości gospodarskiej, słowem - uczyć skutecznego zarządzania domem i gospodarstwem. Stawiano dziewczętom za wzór gospodarność babek i prababek, które, gdy zaszła taka potrzeba, potrafiły wyręczyć nawet własnego męża w wielu pracach i interesach. Krytykowano niewłaściwe wychowanie dziewcząt, które kształcone „[...] powierzchownie, dla zewnętrznej ogłady, dla świata i salonu"71 nie były w stanie podołać trudom prowadzenia gospodarstwa kobiecego. Zbyt mało zajęć praktycznych lub ich brak w wychowaniu dziewcząt powodował, że nie potrafiły one pełnić właści-

67 Tamże, s. 38.

68 [J. G.], Nauka ręcznych robót kobiecych, DdK 1881, nr 10, s. 77.

69 Tamże, s. 78.

70 Tamże; [R.], Roboty ręczne pań naszych, DdK 1883, nr 22, s. 253-254.

${ }^{71}$ [E. z K. P.], Kilka rad starej babuni tyczących się gospodarstwa wiejskiego, DdK 1881, nr 17 , s. 163 . 
wie obowiązków pani domu i gospodyni, zarządzającej sprawami gospodarskimi w domu i majątku oraz służbą. Za najkorzystniejszy okres praktycznej nauki gospodarstwa kobiecego uznawano czas po ukończeniu edukacji w domu lub na pensji, a przed zamążpójściem czy podjęciem pracy zarobkowej. Dorosła już wtedy, zwykle ok. siedemnastoletnia panna, jak pisano, zamiast spędzać czas na bezczynności, rozrywkach i zabawach czy bezsensownym czytaniu romansów, powinna towarzyszyć matce podczas jej prac i zajęć, zapoznając się z praktyczną stroną prowadzenia domu ${ }^{72}$. Gdy zaś panna została przez matkę odpowiednio i starannie do swojej pracy przygotowana, gwarantowano jej szczęśliwe zamążpójście oraz szacunek i miłość ze strony męża. Dobra, pracowita i gospodarna żona, jak pisano, miała być „[...] uosobionym aniołem stróżem mężczyzny [...], każdy jej krok, każde tchnienie i wszelka robota ma na celu uprzyjemnienie życia temu, któremu sama siebie i całe swe życie w ofierze poniosła"73.

$\mathrm{Na}$ stronach DdK matki, których kilkunastoletnie córki nie wyszły jeszcze za maż, znajdowały wskazówki w zakresie wyboru drogi zawodowej, innej niż praca gospodyni w majątku ziemskim. Charakteryzowano różne możliwości pracy dziewcząt poza domem, ze wskazaniem na ich pozytywne i negatywne strony. Pierwszym i najczęściej polecanym zajęciem dla młodych dziewcząt było nauczycielstwo (prywatne lub w szkole), które uważano za naturalne i wrodzone powołanie kobiety. Niewątpliwą wadą tej profesji była ogromna podaż na rynku pracy, dlatego też jedynie najlepiej wykształcone panienki mogły liczyć na dobrą posadę. Sugerowano dziewczętom zajęcie się niezbyt popularnym wśród płci pięknej snycerstwem (rzeźbieniem w drewnie), drzeworytnictwem, emaliowaniem na porcelanie, litografią, a także malarstwem i fotografią. Polecanym zajęciem było także zajmowanie się chorymi w lazaretach czy klinikach, wymagające jednak starannego wykształcenia w kierunku medycyny i higieny. Szerokie pole pracy kobiet otwierało się w handlu strojami, w składach bielizny, sukien i towarów modnych, gdzie panienki mogły zajmować się krojem, szyciem, wreszcie sprzedawaniem ubrań. Polecano także produkcję rękawiczek, kapeluszy, parasoli, kwiatów, zabawek, wyrobów galanteryjnych, pracę $w$ introligatorstwie, szklarstwie, grzebieniarstwie, tapicerstwie, zegarmistrzostwie i jubilerstwie. Przygotowane do pracy panny mogły także starać się o zajęcie w kucharstwie, piekarstwie, cukiernictwie czy ogrodnictwie. Jednak, jak wyraźnie podkreślano, do podjęcia każdej ze wskazanych prac należało pannę odpowiednio przygotować i fachowo wykształcić, by w trudnej życiowej sytuacji mogła zapewnić byt sobie i swojej rodzinie. Podobnie jak w przypadku prac gospodarskich, do których dziewczęta nie były odpowiednio przyuczane, krytykowano ich niewłaściwe, salonowe wykształcenie, które nie przygotowywało do jakiejkolwiek pracy. „Zmiana w wychowaniu cór naszych jest konieczną, bo wychowanie wytworne tylko i konwencjonalne nie usposabia do trybu praktycznego"74 - pisano, nawołując tym samym do reformy kształcenia

72 Tamże; [M. Sz...a], Domownicy, DdK 1882, nr 14, s. 157-158; [R.], Kilka uwag o oszczędności w prowadzeniu domu, DdK 1882, nr 3, s. 25-27.

${ }^{73}$ O zadaniu i pracy kobiet..., DdK 1882, nr 4, s. 37.

${ }^{74}$ DdK 1885, nr 5, s. 49-50. 
dziewcząt. Jednak projekty te pozostawały jedynie w sferze postulatów, ponieważ brakowało szkół fachowych, kształcących w określonym zawodzie czy zajęciu, które mogło stać się podstawą zarobkowania. Autorzy tekstów poświęconych wychowaniu praktycznemu dziewcząt i przygotowaniu ich do pracy zawodowej proponowali utworzenie różnego rodzaju szkół specjalnych, w których panny mogłyby zdobywać wiadomości teoretyczne i umiejętności praktyczne, konieczne w określonym fachu ${ }^{75}$. Jednak nie wszystkie postulaty pozostawały bez echa, ponieważ w doniesieniach bieżących z 1884 r. czytamy o rosnącym powodzeniu kursów handlowych dla panien w Poznaniu, a także o założeniu wyższego kursu żeńskiego z zakresu „[...] higieny i estetyki, z uwzględnieniem obowiązków przyszłej samodzielnej gospodyni domu"76.

Osobnym, istotnym zadaniem dla młodej dziewczyny miało być szerzenie oświaty wśród ludu. Sugerowano dziewczętom, by zamiast pracy nauczycielek domowych, zechciały podejmować się zajęcia nauczycielek ludowych - profesji mniej opłacalnej finansowo, ale dającej dużo więcej satysfakcji i mającej znaczącą rolę społeczną (szerzenie świadomości narodowej i przeciwdziałanie germanizacji). Zadanie nauczycielki ludowej nie ograniczało się jedynie do pracy w szkole, ale do stałego oświecania i umoralniania ludności wiejskiej.

Stać się wzorową nauczycielką ludu, to umieć go oświecać właściwie, umoralniać, uczyć pracy, poszanowania cudzej własności, umiejętności w ulepszaniu swojej, odciągać od pijaństwa, zaradzać lichwie, przez nakłanianie do wzajemnej pomocy - oto trudne, lecz wzniosłe zadanie kobiety naszej ${ }^{77}$.

Inną formą kształcenia dzieci wiejskich było organizowanie kółek nauczania - kiedy panna ukończyła już swoje nauki, miała wystarczająco dużo czasu, by zająć się kształceniem jednego lub kilkorga dzieci z okolicy. Miało to nie tylko podnieść oświatę ludu, ale przede wszystkim chronić przed germanizacją ${ }^{78}$.

Znaczącą rolę w kształtowaniu charakteru oraz umysłów dzieci i młodzieży miały odgrywać odpowiednie lektury. Czytelniczki DdK znajdowały także na stronach pisma porady w zakresie właściwego wyboru książek. Podpowiadano, jakich zasad należało się trzymać przy doborze lektur, „[...] by to czytanie było szlachetną rozrywką i nauką zarazem"79. Czytanie uznawano za kontynuację kształcenia i uzupełnianie zdobytej wiedzy. Szczególnie zalecano podsuwać dzieciom i młodzieży pozycje z zakresu nauczanych przedmiotów, a także książki naukowe, dostosowane do wieku i poziomu wiedzy (historyczne, geograficzne, o treści literackiej, z dziedziny sztuk pięknych), ale i biografie, monografie literackie, pamiętniki, szkice, żywoty, obrazy historyczne, czasopisma, powieści (szczególnie historyczne, podróżnicze), mające także wymiar kształcący. Najlepiej, by książka

75 Tamże, s. 50-51; [Amelia C.], Głos z Warszawy, DdK 1882, nr 20, s. 229-230; nr 21, s. 241-

242; [M. Sz...a], Kilka myśli o pracy, DdK 1882, nr 17, s. 193-194; Fortepian..., s. 309

76 Rozmaitości i rzeczy bieżące, DdK 1884, nr 14, s. 168.

77 [Amelia C.], Głos..., nr 21, s. 242.

78 [B.], Czego żąda..., nr 6, s. 61-62; nr 7, s. 73-74; nr 8, s. 85-86.

79 Wybór książek dla młodzieży, DdK 1882, nr 22, s. 253. 
była w języku polskim, wydana na terenie kraju, dotyczyła polskich realiów, choć nie odrzucano literatury obcej. Literaturę ojczystą zdecydowanie preferowano, uznając jej czytywanie za przejaw patriotyzmu. Zanim jednak dana pozycja trafiła do rąk młodego człowieka, powinna zostać przez matkę przejrzana pod kątem treści niemoralnych czy fałszowania wypadków dziejowych. Wszystkim - zarówno młodszym dzieciom, jak i młodzieży - zalecano książki o tematyce religijnej i moralnej. Sugerowano, by z różnych lektur dzieci wypisywały ważne myśli, fragmenty czy ustępy, próbowały streszczać je, wynotowywały ważne nazwiska, daty czy miejsca - „[...]dla wiedzy i nauki ten trud z pewnością nie byłby marnie podjętym” ${ }^{80}$. W dziale „Kronika literacka” znajdowały się także, szczególnie w okresie świąt Bożego Narodzenia, charakterystyki i opisy książek dla dzieci: dla tych najmłodszych pięknie ilustrowane, głównie bajki czy wierszyki i powiastki, dla dzieci starszych i młodzieży - o tematyce podróżniczej i przygodowej oraz cieszące się ogromną popularnością opowiadania z życia młodych panien. Choć w Poznaniu, jak pisano, trudno było o książki dla dzieci i młodzieży (największe zasługi na polu wydawnictw dla dzieci miał M. Leitbeger), opisywano i streszczano pozycje, które ukazywały się w innych częściach kraju - w Lwowie, Warszawie czy Krakowie ${ }^{81}$.

Podkreślić należy, że w działach „Kronika literacka”, „Kronika literacka i artystyczna” lub „Bibliografia” ukazywały się informacje o książkach dla dzieci i młodzieży oraz o najnowszych pozycjach z różnych dziedzin. Często, obok autora, tytułu, wydawcy i miejsca wydania oraz ceny, za jaką można było daną pozycję nabyć, przedstawiano najistotniejsze treści w nich zawarte. Niekiedy pojawiały się nawet dość wnikliwe i rozbudowane streszczenia i recenzje poszczególnych rozdziałów książek. Bywało tak często w przypadku pozycji dotyczących problematyki wychowawczej. Zainteresowane czytelniczki, szczególnie matki, mogły dowiedzieć się, jakie zagadnienia dotyczące wychowania dzieci i młodzieży w danej pozycji poruszono i podjąć decyzję o przydatności książki, często o charakterze poradnikowym, i jej ewentualnym zakupie ${ }^{82}$. „Niejedna matka pragnie pouczyć się sama, lub założyć biblioteczkę dla swych dzieci, nie umiejąc jednak kierować się w wyborze, natrafiała częstokroć na rzeczy mniejszej wartości - ocena wytrawnych znawców

80 Tamże, s. 253-254; [M. Sz...a], Niektóre przesądy w czytaniu, DdK 1883, nr 9, s. 97-98; [R.], Literatura i książki w życiu kobiet, tamże, nr 2, s. 13-14; [R.], Kilka słów..., s. 146; [Teja], Cudze rzeczy..., s. 278; [K. K.], O czytaniu, DdK 1885, nr 25, s. 97-98; Książki dla młodzieży i ich znaczenie, [w:] Korespondencja „Dwutygodnika”, DdK 1880, nr 2, s. 16.

${ }^{81} \mathrm{Na}$ Gwiazdkę, [w:] Kronika literacka, DdK 1882, nr 8, s. 92.

82 „Ksiądz Chotkowski wzbogacił swą książką katolicką literaturę polską, a społeczeństwu wielką wyświadczył przysługę. [...] Zatrzymano się umyślnie nieco dłużej nad rozbiorem tej książki, aby czytelniczkom naszym dać sposobność do poznania jej treści, która nas tak blisko dotyka, a matki i osoby wychowujące zachęcić do jej nabycia”, [w:] O wychowaniu dzieci..., s. 134; „Zwracamy publiczności naszej uwagę na dzieło «O wychowaniu macierzyńskim» przez Zofią Kowerską, premiowane na konkursie ogłoszonym przez redakcją «Bluszczu» [...]”, [w:] Kronika literacka, DdK 1882, nr 19, s. 226; zob. też np.: Wychowanie dziecka włącznie do lat sześciu..., s. 81; Bibliografia, DdK 1883, $\mathrm{nr}$ 8, s. 88; Elementarz poznański dla użytku szkół elementarnych, publicznych i prywatnych, podług mieszanej metody pisania i czytania, opartej na głosowaniu, oprac. F. Krajewicz, A. Modrzyński, z wielu rycinami, DdK 1884, nr 2, s. 22-23; W Warszawie wyszedł „Rocznik Pedagogiczny”, [w:] Przegląd literacki, DdK 1885, nr 25, s. 106-107. 
może być jej zatem bardzo pożyteczną"83 - pisano. Pojawiały się także ogłoszenia informujące o czasopismach dla dzieci i młodzieży ${ }^{84}$.

$\mathrm{Na}$ łamach analizowanego pisma autorzy artykułów dotyczących wychowania zwracali też uwagę na wychowawczą rolę zabaw dziecinnych. Za szczególnie istotne dla rozwoju dziecka uważano zabawy z rówieśnikami, które nie tylko kształtowały umiejętności współpracy, walki, przegrywania lub zwycięstwa, lecz także były bardziej atrakcyjne, pomysłowe i wesołe niż zabawy w pojedynkę. Kiedy dzieci nie miały towarzystwa rodzeństwa, sugerowano wybrać kolegę czy koleżankę z okolicy, choćby z gminu, mniej więcej w podobnym wieku, których należało nauczyć grzeczności i pozwolić rówieśnikom na swobodną zabawę. Dzieci powinny bawić się pod nadzorem osoby dorosłej, której zadaniem było dbać o ich bezpieczeństwo. Dorośli mieli pozostawić jednak najmłodszym swobodę podczas zabaw, nie powinni ingerować w ich przebieg, krępować dzieci napomnieniami czy zakazami. Nadzorowanie zabawy dzieci miało też pozwolić rodzicom, szczególnie zaś matkom czy bonom i nauczycielkom, poznać charakter i usposobienie dziecka. „Nie zna dziecka, kto go nie uważał podczas zabawy [...]. Co postrzeżemy przy zabawie, niech nam będzie wskazówką, jak sobie z dzieckiem postępować, nad którą z jego skłonności najbardziej pracować, co w nim prostować trzeba"85 - radziła M. Sz...a. Zabawę uważano także za świetny sposób nauczania - niepostrzeżenie i „przy okazji” można było dziecku przekazać pewne zasady, spostrzeżenia czy wiadomości ${ }^{86}$. Wśród zabaw dziecięcych powinny być zabawy ruchowe: biegi, skoki, gonitwy i inne, ponieważ pozwalały one rozładować napięcie i dawały gwarancje „,...] ochraniania małych od pomysłów dziwacznych, rodzących się w główkach i wykonywanych dla zabicia czasu, dla zajęcia chwilowego"87. Zwracano także uwagę na zabawki dzieci, które powinny być bezpieczne, proste, niezbyt kosztowne, dostosowane do wieku i poziomu rozwoju dziecka. Radzono podpowiadać maluchom, jak podczas zabaw wykorzystywać przedmioty codziennego użytku i dary przyrody ${ }^{88}$.

$\mathrm{Na}$ łamach DdK znajdujemy także teksty poświęcone problematyce wychowania fizycznego, zdrowotnego, higieny dzieci i młodzieży. Publicyści z trwogą podawali statystyki śmiertelności dzieci do lat 5, które na początku lat osiemdziesiątych XIX stulecia wynosiły $50 \%$ ogólnej liczby zmarłych. Postulowali konieczność reformy w zakresie opieki i pielęgnacji małych dzieci. Krytykowano niewłaściwe zachowanie ciężarnych, które stylem życia, spędzaniem czasu na

83 Tamże, s. 106.

84 "«Towarzysz Dzieci» - jedyne na Galicję i Wielkie Księstwo Poznańskie ilustrowane czasopismo dla młodego wieku, wychodzi we Lwowie od lat siedmiu, pod redakcją Władysława Bełzy. «Towarzysz», obok rycin w tekście, dołącza co kwartał kolorowaną chromolitografię, jako premię dla dzieci. Cena tego pisemka, które najlepiej prenumerować za pośrednictwem księgarni F. H. Richtera we Lwowie, wynosi rocznie 10 Mrk, półrocz. 5 Mrk.”, DdK 1882, nr 10, s. 120.

${ }^{85}$ [M. Sz...a], Kiedy się ma rozpoczynać..., s. 25.

86 O zadaniu i pracy..., nr 4, s. 38; [B. Ł.], Słów kilka..., s. 193-194; Pogadanki o wychowaniu..., nr 13, s. 145.

87 Tamże, nr 14, s. 158

88 Tamże, nr 15, s. 169; Jak należy pojmować..., s. 233. 
nieodpowiednich dla swojego stanu rozrywkach lub zbyt ciężkiej pracy, złym odżywianiem i strojem powodowały zaburzenia w rozwoju płodu, przyczyniały się do trudnych i skomplikowanych porodów. Zarzucano matkom dobrze sytuowanym, że nie karmią samodzielnie dzieci piersią, oddając je w ręce mamek, a dzieci starsze przypadkowo dobranym niańkom, piastunkom czy bonom. Przyczyną zgonów dzieci było pozostawianie ich bez opieki, szczególnie wśród mniej zamożnych warstw społecznych ${ }^{89}$. "lleż to dzieci we wszystkich społeczeństwa sferach wychowano tym sposobem na ludzi przez cale życie schorzałych i cierpiących na skutek niehigienicznego żywienia i nieprawidłowego starania o rozwój sił fizycznych"90 - pisano. Uświadamiano czytelniczki, czym jest racjonalne fizyczne wychowanie i jaki jest jego cel:

Celem dobrego, fizycznego wychowania dzieci jest nadanie ich organizmowi jak najwięcej sił, staranie się o jak najmocniejsze wyrośnięcie kości, o jak najsilniejsze rozwinięcie się mięsiw, o nadanie im dobrego odżywiania ciała, zostawiając całość w dobrych kształtach, w pewnej zgrabności i urodzie, obok krzepkości i jędrności ${ }^{91}$.

Teksty z zakresu zdrowia i higieny pisali najczęściej znani i cenieni lekarze, których autorytet miał świadczyć o wadze zagadnienia i skłaniać czytelniczki do stosowania publikowanych zaleceń. Troska o zdrowie i higienę rodziny oraz dzieci była zadaniem kobiety - pani domu, matki ${ }^{92}$ - i opierała się na prostych zasadach: umiarkowaniu w jedzeniu i picu, zażywaniu jak największej dawki ruchu fizycznego, świeżego powietrza i wody. Ich złamanie powodowało choroby i stawało się przyczyną tak wysokiej śmiertelności, szczególnie wśród najmłodszych. Żeby więc dziecko zdrowo rosło i dobrze się rozwijało, zalecano zapewnić mu zdrowe i obfite, ale niewykwintne jedzenie, czysty i dostosowany do pory roku, niekrępujący ruchów ubiór, codzienną higienę, unikanie lenistwa, częste przebywanie na świeżym powietrzu i korzystanie ze światła słonecznego, przebywanie w pomieszczeniach suchych i nieprzegrzanych ${ }^{93}$. „Zdrowie ciała wymaga ruchu codziennego, przechadzki i pracy ręcznej, jak największej czystości ciała, umiarkowania i wstrzemięźliwości" ${ }^{94}$ - radziła E. z K.P.

Zalecenia higieniczne zaczynały się już od okresu niemowlęctwa - nie należało ubierać dzieci w ciasne sukienki i powijaki, krepujące ruchy i ściskające klatkę piersiową i nóżki, wykluczano przykrywanie ich grubymi puchowymi pościelami oraz

${ }^{89}$ [A. M.], Towarzystwo Przyjaciół Dzieci..., nr 18, s. 175-176.

90 Tamże, s. 176.

91 O fizycznym wychowaniu dzieci..., nr 15, s. 176.

92 „Jej przypada troska o pielęgnowanie zdrowia wszystkich do ogniska domowego należących osób, tak członków familii, jak i osób obcych, i to przez troskliwe zabiegi około pożywnego pokarmu, około stosownej odzieży i około zdrowo utrzymanego mieszkania”, [w:] Rozmaitości i rzeczy bieżące, DdK 1884, nr 14, s. 168.

93 [R.], Kobieta..., s. 61; Jak należy pojmować..., s. 233; [E. z K. P.], Wieczorne pogadanki... O zdrowiu, DdK 1882, nr 23, s. 265; O zadaniu i pracy..., nr 4, s. 38; [J. D.], Piękność i kosmetyki, DdK 1883, nr 8, s. 88; [R.], Nieco o modzie i strojach, DdK 1883, nr 16, s. 181-182.

94 Wieczorne pogadanki... O szczęściu, s. 62. 
przegrzewanie. Płacz dziecka także nie powinien być powodem do niepokoju, ponieważ rozszerzać miał płuca i piersi. Nie należało dziecka nosić zbyt długo na ręku, ponieważ tamować to miało przepływ krwi, zaś najkorzystniejsze dla zdrowia malucha było pozostawienie go w bezpiecznym miejscu, np. na podłodze, by mógł poruszać kończynami, uczyć się raczkować i chodzić ${ }^{95}$.

Stosunkowo wiele uwagi poświęcano właściwemu odżywianiu dzieci. Problematykę tę omawiał np. obszerny, opublikowany w 1883 r. w trzech częściach, artykuł dr. Klemensa Kochlera. Niemowlęta powinny być karmione piersią matki, jeśli ta jednak nie mogła karmić sama, powinna poradzić się lekarza odnośnie do karmienia sztucznego. Dzieci starsze otrzymywały tyle jedzenia, ile potrzebowały, w zależności od wieku i trybu życia. Zbyt duża ilość pokarmu, szczególnie w przypadku spędzania czasu nad książkami u dzieci w wieku szkolnym, powodowała ociężałość i prowadziła do łakomstwa. Nie należało jednak przesadnie ograniczać dzieciom ilości spożywanych posiłków, zaś karanie głodem za wykroczenia krytykowano szczególnie. Dziecko powinno jadać 5 razy dziennie pokarmy urozmaicone. Podawano konkretne potrawy, którymi można było karmić maluchy i dzieci starsze, z podaniem pór posiłków i ich dokładnego składu, a także sposobami przygotowania, by nie traciły swych właściwości odżywczych. W menu dziecięcym szczególnie zalecano mleko, jaja, mięso, warzywa, owoce i zboża. Z napojów szczególnie korzystna dla dziecka była woda, odradzano wszelkie kawy, herbaty, wina czy piwo ${ }^{96}$.

Zwracano także uwagę na odpowiedni strój dziecka, dostosowany do temperatury otoczenia, wieku i płci, niekrępujący ruchów. Podpowiadano, z jakich materiałów należało szyć dziecinne ubrania w zależności od pory roku. Pisano także, jakie obuwie powinno się dobierać dla najmłodszych, by nie koślawiło stopy i było wygodne ${ }^{97}$.

Czystość ciała była także uznawana za niezbędny warunek zdrowia. Małe dzieci powinny być kąpane codzienne, starsze przynajmniej dwa razy w tygodniu zimą oraz codziennie latem ${ }^{98}$. W ukazującym się przez kilka numerów 1881 r. cyklu Notatki z dziedziny nauk przyrodniczych i higieny autorstwa dr. Koszutskiego sporo miejsca poświęcono higienie włosów dzieci. Publicysta radził matkom, jak mają postępować $z$ włoskami niemowląt, by te rosły silne i zdrowe. Żeby pobudzić wzrost włosów, zalecał codzienne mycie głowy w ciepłej wodzie z mydłem glicerynowym. Nie polecał zakładania czapek czy czepków, pod którymi włosy się przetłuszczały. Radził, jak postępować z nagromadzonymi na główce łuskami suchego łoju, tzw. ciemieniuszką, którą należało smarować gliceryną lub oliwą tak długo, aż odpadła. Starszym dzieciom należało czesać włosy szczotką lub grzebieniem, bez zastosowania pomad czy pachnących olejków. Nie powinno się nawijać włosów dzieci na papiloty ani prostować ich żelazkami, gdyż się przesuszały, słabły i wypadały. Strzyżenie miało także znaczenie w trosce o zdrowie dzieci, np. zimą

${ }_{95}$ [E. z K. P.], Wieczorne pogadanki... O zdrowiu..., nr 5, s. 50.

96 Przy stole..., s. 217; O fizycznym wychowaniu..., nr 15, s. 176-177; nr 17, s. 200-202; nr 18, s. $212-213$.

97 Tamże, nr 18, s. 213; nr 19, s. 225-226.

98 Tamże, s. 226. 
zbyt krótkie włosy nie chroniły wystarczająco od zimna, dłuższe zaś skutecznie osłaniały kark i uszy przed chłodem, a więc i przed przeziębieniami99.

Osobny artykuł został poświęcony higienie jamy ustnej i zębów. Ich zdrowie zależało od właściwej pielęgnacji już od najmłodszych lat. Matki miały za zadanie pilnować, by dzieci nie gryzły twardych łupin orzechów, sznurków, zabawek, które niszczyły szkliwo, a także właściwie czyściły zęby. Zalecano płukanie ust wodą po każdym posiłku, mycie ich szczoteczką i kredą z olejkiem miętowym, szczególnie wieczorem. Odradzano spożywanie słodyczy i cukru. Od 6. roku życia polecano doroczne wizyty u dentysty ${ }^{100}$.

Sporo miejsca poświęcono higienicznemu urządzeniu pokoju dla dziecka. Przede wszystkim pokój, w którym maluch spędzał najwięcej czasu, czy to na zabawie, czy na nauce, musiał być często wietrzony, dokładnie sprzątany, a więc „wolny o kurzu, wszelkich wyziewów i złych zapachów”"101. Nie zalecano ogrzewania piecem żelaznym, ponieważ był niebezpieczny ze względu na wydobywający się czad, lecz za pomocą pieca kaflowego. Podłoga w pokoju dziecinnym powinna być pozbawiona dywanów, które stawały się siedliskiem kurzu i bakterii. Pokoik dziecinny miał być urządzony z pewnym smakiem, tzn. zalecano wieszanie obrazków, stosownych do wieku dziecka, jasne meble i obicia, kwiaty. Opisywano, jak przygotować higieniczne i zdrowe dla dziecka łóżeczko i łóżko, zalecając materac włosiany, cienką kołderkę i poduszkę, odradzając zaś pierzyny i stosy poduszeczek, powodujących skrzywienia kręgosłupa ${ }^{102}$.

Zdrowe dzieci powinny codziennie spędzać kilka godzin na świeżym powietrzu. Najlepiej, by spacerowały i biegały w okolicy łąk, lasów, parków, w miastach zalecano wyprawy za miasto, gdzie powietrze było czyste i zdrowsze ${ }^{103}$. Ruch na świeżym powietrzu nie tylko miał przyczynić się do wzmocnienia sił fizycznych, lecz także zapobiegać suchotom - chorobie, na którą zapadała znaczna liczba dzieci, szczególnie z niższych warstw społecznych. Dlatego też dla dzieci możnych zalecano od najwcześniejszych lat „turnowanie” (uprawianie ćwiczeń fizycznych - biegów, skoków, gonitw i gimnastyki), jazdę konną, fechtowanie ${ }^{104}$. Gdy pogoda dopisywała, proponowano zimne kąpiele w rzece lub basenie, połączone z pływaniem, zarówno dla chłopców, jak i dla dziewcząt. Wszelki ruch fizyczny (spokojny spacer, biegi, gonitwy, jazda na łyżwach, gimnastyka ${ }^{105}$ ) był uważany za zbawienny dla zdrowia. Osobną uwagę poświęcono także higienie szkolnej, pisząc, że dzieci przebywające cały dzień w szkole powinny mieć zajęcia z „turnowania", odpowiednio dobrane do wieku zestawy ćwiczeń fizycznych. Postulowano zmianę ławek szkolnych, biurek i krzeseł, które powodowały wady kręgosłupa ${ }^{106}$.

99 Tamże, s. 225-226.

100 Dlaczego psują się zęby tak szybko u dzisiejszego pokolenia i co trzeba czynić, aby tej klęsce zapobiedz?, DdK 1882, nr 6, s. 69-70.

101 O fizycznym wychowaniu..., nr 18, s. 212.

102 Tamże, s. 213.

103 Tamże, nr 15, s. 176.

104 [E. z K. P.], Wieczorne pogadanki... O zdrowiu, nr 5, s. 49.

105 O fizycznym wychowaniu..., nr 19, s. 226.

106 [E. z K. P.], Wieczorne pogadanki... O zdrowiu, s. 50. 
Krytykowano niewłaściwe postawy matek i ojców, którzy często chorujące dzieci pozbawiali wszelkiego kontaktu z powietrzem, słońcem i ruchem fizycznym; realizując tzw. wychowanie cieplarniane, delikatne, zamiast pomagać, pogarszali jeszcze ich stan ${ }^{107}$. Kiedy któryś z domowników chorował, czytelniczki DdK mogły na łamach rocznika z 1884 r. znaleźć skuteczne lekarstwo na każdą niemal dolegliwość (także dziecięcą) w cyklu artykułów o charakterze poradnikowym pt. Domowa apteka. Teksty zawierały przepisy na przyrządzanie leków wywarów, olejków, nalewek, herbat, naparów, proszków, esencji z ziół zbieranych na polach, w ogrodach i lasach ${ }^{108}$. W jednym z artykułów z 1885 r. matki mogły znaleźć cenne informacje na temat objawów, przebiegu i sposobów zapobiegania dziecięcym chorobom odzwierzęcym ${ }^{109}$.

Niewątpliwie istotną rolę $\mathrm{w}$ organizacji wychowania i kształcenia dzieci odgrywały ogłoszenia, zamieszczane na łamach pisma, zwykle na ostatniej stronie. Zainteresowani mogli tam bowiem znaleźć informacje o istniejących na ziemiach polskich biurach nauczycielskich, pośredniczących w zatrudnianiu dla rodzin z Księstwa Poznańskiego nauczycieli i nauczycielek domowych oraz bon ${ }^{110}$. Przełożone pensji żeńskich informowały społeczeństwo o naborach na kolejny rok szkolny, zachwalając jednoczenie swoją kadrę pedagogiczną ${ }^{111}$. Właścicielki pensjonatów reklamowały swoje stancje w mieście, zapewniając jednocześnie dziewczętom guwernantki cudzoziemki112. Dziewczęta, chcące kształcić się na nauczycielki, znajdowały tam oferty kursów - zarówno freblowskich, jak i z zakresu nauczania talentów ${ }^{113}$.

107 "Gdyby matki rodziny znały się na higienie, nie pozbawiałyby dzieci światła słonecznego i czystego powietrza, które są głównymi czynnikami zdrowia, a nawet życia" - pisała E z K. P., [w:] [E. z K. P.], Wieczorna pogadanka starej babuni. Kilka słów o oszczędności, DdK 1885, nr 9, s. 98; por. $\mathrm{t}$ a ż, Wieczorne pogadanki... O zdrowiu, s. 49; DdK 1882, nr 23, s. 266; Z higieny, DdK 1884, nr 2, s. 21-22.

108 Zob. np.: Apteka domowa z roślin zbieranych w ogrodach, polach, lasach etc. Podług wykładów dra A. Schilinga napisała E. z Kurowskich Puffke, DdK 1884, nr 21, s. 251.

${ }_{109}$ Zwierzęta domowe, jako krzewiciele chorób ludzkich. Podług rozprawy dra Sonnenbergera napisała E z K. P., DdK 1885, nr 11-12.

110 „Biuro Nauczycielskie Heleny Nowoleckiej w Krakowie. 25 lat istnieje już ten zakład [...] podpisana ma zaszczyt zawiadomić, że zakład jej i na przyszłość pozostanie na dotychczasowej stopie, starając się o życzliwość i poważanie Ogółu, a pożytek młodzieży, a więc nadal pośredniczyć będzie w wyborze nauczycielek i nauczycieli odpowiednio kwalifikowanych, z wykształceniem szkolnym lub domowym, w języku ojczystym, jak również i obcych: francuskim, niemieckim, angielskim, tudzież w muzyce, śpiewie i rysunkach oraz bon, tak z kraju jak i z zagranicy, dla Galicji z Bukowiną, Królestwa, Cesarstwa Rosyjskiego i Wielkiego Księstwa Poznańskiego. Helena Nowolecka, ulica Gołębia Niższa nr 183", DdK 1881, nr 14, s. 136.

111 „Kurs nauk w wyższej, sześcioklasowej szkole żeńskiej PP. Danysz, będącej pod dyrekcją Prof. Dr. Mottego (Plac Piotra nr 3) rozpocznie się w środę 13 października. Egzamin nowo wstępujących uczennic we wtorek dnia 12 października od 3 godziny począwszy", DdK 1880, nr 1, s. 8.

112 „Od 15 października r.b., jako z początkiem roku szkolnego, przyjmuję pensjonarki nowe, kształcące się prywatnie, jako też uczęszczające do tutejszych wyższych zakładów naukowych. W pensjonacie moim jest nauczycielka Paryżanka, posiadająca przy tym gruntownie język angielskie. Teofila Radońska, Poznań, Wiedeńska ulica, nr 5, I piętro", DdK 1884, nr 1, s. 12.

113 „Dla pań, chcących się kształcić na nauczycielki tańca i gimnastyki mam zamiar urządzić kurs osobny. Zgłoszenia przyjmuję każdego czasu. A. Lipiński, nauczyciel tańca, Poznań, stare gimna- 
Obok dominujących w DdK artykułów o tematyce związanej z wychowaniem domowym dzieci i młodzieży, od czasu do czasu ukazywały się teksty, które dotyczyły wychowania w placówkach i instytucjach wychowawczych. W numerach 4, 6 i 7 z 1880 r. opublikowano artykuł, dotyczący wychowania nieletnich w instytucjach karno-poprawczych autorstwa H. J. Boguskiej, posługującej się pseudonimem Hajota. Publicystka opisywała funkcjonowanie pierwszej i wówczas jedynej takiej instytucji w Królestwie Polskim. Cenne i wartościowe poznawczo było ukazanie historii opieki nad nieletnimi pozbawionymi opieki, sierotami, podrzutkami, dziećmi opuszczonymi, żebrakami, włóczęgami, małoletnimi przestępcami w Szwajcarii, Holandii, Francji, Belgii, we Włoszech, w Niemczech, Anglii czy Rosji, a także na ternie Królestwa Polskiego od drugiej połowy XVIII po lata siedemdziesiąte XIX w., wraz z opisem stosowanych w nich systemów wychowawczych. Funkcjonujące za granicą instytucje wychowawcze dla nieletnich stały się inspiracją dla Tadeusza Lubomirskiego, który wraz z Józefem Wieczorkowskim podjął inicjatywę utworzenia Towarzystwa Osad Rolnych i Przytułków Rzemieślniczych, zatwierdzonego przez ministra sprawiedliwości w 1872 r. Po licznych trudnościach organizacyjnych otwarcie osady nastąpiło w 1876 r. Towarzystwo działało w guberni warszawskiej, powiecie skierniewickim, w gminie studzienickiej. Było oparte na systemie mieszanym, a mianowicie dzielono chłopców na rodziny, klasy i oddziały, w ramach których wspólnie mieszkali, uczyli się i pracowali. Hajota dokładnie przedstawiła osadę, jej położenie, urządzenie domków dla dzieci, plan dnia, a nawet ubiór chłopców. Celem artykułu było przybliżenie działalności określonej placówki, ale przede wszystkim uświadomienie czytelnikom sensu podejmowanych zabiegów wychowawczych wobec dzieci trudnych i zdemoralizowanych, które dzięki takim placówkom miały szansę stać się prawymi obywatelami. Bogucka, kończąc wnikliwy opis uroczystości rocznicy otwarcia zakładu w Studzieńcu, apelowała do społeczeństwa Księstwa Poznańskiego o zwrócenie uwagi na problemy nieletnich i podjęcie próby założenia podobnej placówki wychowawczej ${ }^{14}$.

Istotną rolę odegrał publikowany w kilku numerach DdK artykuł poświęcony działalności Towarzystwa Przyjaciół Dzieci (TPD) w Warszawie. Choć w czasie, kiedy tekst się ukazywał, Towarzystwo pozostawało dopiero w fazie koncepcji, przedstawiono dzieje jego powstania, pomysłodawców, zadania, cele i środki jego funkcjonowania, skład, władze, a także prawa i obowiązki członków. Za najważniejszy cel TPD uznano wpływ na rozwój młodych pokoleń przez niesienie matkom pomocy materialnej i moralnej, szerzenie wiedzy na temat zdrowa i pielęgnowania dzieci (publikacje, odczyty, wystawy), pomoc kobietom brzemiennym, popieranie karmienia piersią i pielęgnowania dzieci przez matki, roztaczanie opieki nad dziećmi od momentu narodzin, chroniące przed różnego rodzaju niebezpieczeństwami (fizycznymi, moralnymi), nadzorowanie osób opiekujących

zjum", DdK 1884, nr 2, s. 12; zob. też: Kurs zabaw i rozwijania umysłu dzieci podług systemu Froebla, DdK 1884, nr 1, s. 12.

114 H. J. B o g u s k a [Hajota], O instytucjach karno-poprawczych dla nieletnich, DdK 1880, $\mathrm{nr} 4$, s. $25-27$; nr 6, s. 47-48; nr 7, s. 55-57. 
się dziećmi (akuszerki, mamki, piastunkami, bony, nauczyciele), niesienie pomocy materialnej rodzinom ubogim i dzieciom opuszczonym, umieszczanie ich w odpowiednich zakładach i placówkach wychowawczych, powoływanie do życia nowych zakładów opieki nad dziećmi, zapewnianie ubogim dzieciom opieki lekarskiej, pociągnie do prawnej odpowiedzialności osób nadużywającej władzy nad dziećmi i wyróżnianie osób zasłużonych na polu opieki nad nimi. Autor zapoznaje czytelniczki z głównymi zarzutami pod adresem projektu funkcjonowania Towarzystwa, wyjaśnia idee organizatorów, zatrzymuje się dłużej przy istocie macierzyństwa, stanowiącego istotę życia każdej kobiety, ukazuje cierpienia i niedole matek z rodzin ubogich, ale przede wszystkim trudną sytuację ich dzieci, którym Towarzystwo miało nieść pomoc już od chwili poczęcia ${ }^{115}$.

Problematyka instytucji wychowawczych znalazła także swoje odzwierciedlenie w tekstach dotyczących zakładania ogródków freblowskich. Wyjaśniano ideę Fryderyka Froebla i zamysł jego systemu pedagogicznego, sugerując, by każda matka wnikliwie się z tymi poglądami zapoznała, próbując stać się „ogrodniczką" dla własnego dziecka. Wskazywano korzyści płynące z poszczególnych zajęć, polecanych przez Froebla dla małych dzieci. Robótki ręczne, gimnastyka, modelowanie i musztra miały wzmacniać elastyczność ciała i wyrabiać zręczność, opowiadania i wierszyki rozwijały zdolności umysłowe, zaś rysunki i śpiew - zmysł wzroku i słuchu. Uczęszczające do ogródków dzieci w wieku do lat 7 przyzwyczajano do porządku, wypełniania poleceń i zadań, kształtowano ich poczucie obowiązku, rozwijano umysł poprzez zabawę $e^{116}$. Opisywano funkcjonowanie ogródków, zwracając szczególną uwagę na rolę kierowniczki-ogrodniczki, bez której rośliny-dzieci nie będą właściwie wzrastały. „Winna być to kobieta wykształcona, dobrze wychowana, obdarzona tkliwym sercem niewieścim, a przede wszystkim z prawdziwym zamiłowaniem oddająca się zawodowi"117. Proponowano zwiększenie liczby tego typu placówek zarówno w miastach i miasteczkach, jak i na wsiach. Placówki te miały być doskonałym miejscem pracy dla młodych wykształconych dziewcząt, które bezskutecznie poszukiwały pracy jako nauczycielki ${ }^{118}$. Na łamach pisma ukazywały się także ogłoszenia dotyczące zajęć dla dzieci w ogródkach freblowskich oraz kursów, na których chętne dziewczęta mogły się nauczyć pracy z małymi dziećmi według systemu Froebla ${ }^{119}$.

Na łamach DdK charakteryzowano także funkcjonowanie kursów i szkół dla dziewcząt oraz zamieszczano sprawozdania z popisów szkolnych, odbywających

115 [A. M.], Towarzystwo Przyjaciół Dzieci..., nr 17, s. 163-165; nr 18, s. 174-176; nr 20, s. 198-199.

116 [L.], Słówko o ogródkach froeblowskich, DdK 1881, nr 11, s. 99-100; [R.], O wczesnym rozwijaniu..., s. 229-230; O fizycznym wychowaniu..., nr 15, s. 176; [Marya S.], Majówka (wrześniówka) dzieci szkółki froeblowskiej p. H. Z., [w:] Wiadomości literackie, rozmaitości i rzeczy bieżące, DdK 1884, nr 85, s. 300.

117 [L.], Słówko..., s. 100.

118 O zadaniu i pracy..., nr 5, s. 50

119 „Kurs zabaw i rozwijania umysłu dzieci podług systemu Froebla rozpoczyna się w szkółce mojej dnia 17 b.m. Zgłoszenia dzieci przyjmuję każdego czasu. H. Radońska, Poznań, Piekary nr 16, I piętro", DdK 1884, nr 1, s. 12. 
się w szkołach żeńskich Księstwa Poznańskiego. Dokładnie opisywano system kształcenia w danej szkole, jej program, warunki nauki oraz jej rezultaty - popisy i egzaminy uczennic. Informowano o zakładaniu kursów z zakresu różnych nauk dla panien, wśród których szczególnym zainteresowaniem cieszyły się kursy handlowe oraz higieny i estetyki. Sprawozdania i doniesienia obfitowały w cenne informacje dla rodziców, chcących posłać swe córki do szkół żeńskich ${ }^{120}$.

DdK ukazywał się zaledwie przez 5 lat. W numerze 1. z 1882 r. redaktorka pisała: „W naszych stosunkach, wśród garstki naszego społeczeństwa wydawać pismo czasowe, a do tego literackie i beletrystyczne - to zaprawdę nie powodzenia, ale na każdym kroku trudu i walki oczekiwać trzeba"121. Redakcja pisma miała ambicję uczynienia z niego głównego organu prasowego kobiet wielkopolskich. Apelując do serc i umysłów czytelniczek, polecano jego czytywanie, gdyż krzewi polskość, religię i pozwala poznawać bieżącą sytuację w kraju ${ }^{122}$. Rozpoczynając ostatni, piąty rok wydawania pisma, otwarcie prezentowano przeszkody i trudności, z jakimi się borykało. Problemy materialne, niewielkie grono prenumeratorów i czytelników, brak szerszego zainteresowania ze strony społeczeństwa powodowały, że redakcja z obawą myślała o jego przyszłości ${ }^{123} .26$ września 1885 r., po 5 latach ukazywania się dwutygodnika, wydano jego ostatni numer. Redakcja informowała zainteresowanych czytelników o zmianach w wydawnictwie i publikacji pierwszego numeru „Tygodnika Beletrystycznego i Naukowego”124, zastępującego DdK. Witold Jakóbczyk, analizując problematykę prasy wielkopolskiej końca XIX w. pisał, że przyczyną małego powodzenia pism była nie tylko obojętność społeczeństwa, które nie nawykło do stałego kontaktu z prasą, lecz także niski poziom czasopism wielkopolskich. Wszystkie te czynniki sprawiły, że DdK szybko przestał się ukazywać, nie znajdując szerszego oddźwięku wśród czytelniczek ${ }^{125}$.

Podkreślić jednak należy, że mimo krótkiego okresu ukazywania się, czasopismo mogło pełnić rolę istotnego poradnika wychowawczego dla czytelników-rodziców, a w głównej mierze matek. Zamieszczane na łamach DdK artykuły ujawniały błędy i braki domowego wychowania młodego pokolenia, służąc jednocześnie radą, co czynić, by błędy te naprawić. Choć artykuły z dziedziny wychowania były nacechowane konserwatyzmem i tradycjonalizmem, szczególnie w zakresie wychowania i wykształcenia dziewcząt, to wiele zaleceń można uznać za wartościowe i szczególnie istotne w warunkach zaboru. Podkreślić należy troskę o język ojczysty, wychowanie w duchu poszanowania historii polskiej i religii,

${ }^{120}$ W 1882 r. zamieszczono charakterystykę popisów i egzaminów uczennic z poznańskich szkół Pani Danysz, Warnki i Estkowskiej, [w:] Nasze wyższe szkoły średnie, Rozmaitości i rzeczy bieżące, DdK 1882, nr 1, s. 11-12; w 1884 r. opisywano szczególne powodzenie kursów żeńskich z zakresu handlu oraz higieny i estetyki, [w:] Rozmaitości i rzeczy bieżące, DdK 1884, nr 14, s. 168; [J.], Z pod Śremu, w grudniu 1884, [w:] Korespondencja „Dwutygodnika”, DdK 1885, nr 7, s. 81; Egzamin uczennic wyższej szkoły żeńskiej p. Anastazji Warnki, [w:] Rozmaitości i rzeczy bieżące, DdK 1884, nr 1, s. 11.

121 Od redakcji, DdK 1882, nr 1, s. 1.

122 Tamże, s. 2.

123 Od redakcji, DdK 1884, nr 1, s. 1-2.

124 Od redakcji, DdK 1885, nr 26, s. 308.

125 W. Ja k ó b c z y k, Prasa..., s. 188. 
będących podstawą kształtowania patriotyzmu młodego pokolenia. Wprawdzie zalecenia w zakresie kształcenia umysłowego i nauczania domowego dziewcząt oraz przeznaczenia kobiety przypominały twórczość Klementyny z Tańskich-Hoffmanowej (pierwsza połowa XIX w.), ale w sposób adekwatny do zmieniających się warunków społecznych i gospodarczych zaczęły się pojawiać postulaty przygotowania praktycznego i zawodowego dziewcząt. Z pewnością pomocne były dla rodziców i wychowawców publikowane regularnie streszczenia i recenzje najnowszych książek z dziedziny wychowania oraz literatury dla dzieci i młodzieży. Niezwykle cenne, będące konsekwencją rozwoju higieny i nauk medycznych, okazywały się porady w zakresie wychowania fizycznego dzieci i młodzieży, pisane przez specjalistów w danej dziedzinie i oparte na wynikach najnowszych badań. Z kolei w licznych artykułach dotyczących wychowania moralnego dzieci i młodzieży oraz charakterystyki obowiązków i zadań wychowawczych matek można odnaleźć wskazówki i zalecenia, które i dziś, mimo zupełnie odmiennych warunków funkcjonowania, uznać można za aktualne.

DdK stanowi wartościowe źródło do badania poglądów publicystów na temat roli kobiet w życiu rodzinnym, społecznym i zawodowym drugiej połowy XIX w., form i sposobów przeciwdziałania germanizacji i krzewienia patriotyzmu, analizy publicystyki literackiej, ukazującej się na jego łamach, a także poradnictwa dotyczącego życia codziennego mieszkańców Wielkopolski - rozrywki, spędzania wolnego czasu, higieny, zdrowia i lecznictwa, kuchni czy ogrodnictwa. 